\title{
Review \\ The Role of Adipose Stem Cells in Bone Regeneration and Bone Tissue Engineering
}

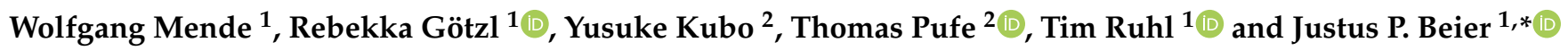 \\ 1 Hand Surgery-Burn Center, Department of Plastic Surgery, RWTH Aachen University Hospital, \\ 52074 Aachen, Germany; wmende@ukaachen.de (W.M.); rgoetzl@ukaachen.de (R.G.); \\ truhl@ukaachen.de (T.R.) \\ 2 Department of Anatomy and Cell Biology, RWTH Aachen University Hospital, 52074 Aachen, Germany; \\ ykubo@ukaachen.de (Y.K.); tpufe@ukaachen.de (T.P.) \\ * Correspondence: jbeier@ukaachen.de; Tel.: +49-241-808-9700
}

Citation: Mende, W.; Götzl, R.; Kubo, Y.; Pufe, T.; Ruhl, T.; Beier, J.P. The Role of Adipose Stem Cells in Bone Regeneration and Bone Tissue Engineering. Cells 2021, 10, 975. https://doi.org/10.3390/cells10050975

Academic Editors: Björn Behr and Levkau Bodo

Received: 1 March 2021

Accepted: 20 April 2021

Published: 21 April 2021

Publisher's Note: MDPI stays neutral with regard to jurisdictional claims in published maps and institutional affiliations.

Copyright: (c) 2021 by the authors. Licensee MDPI, Basel, Switzerland. This article is an open access article distributed under the terms and conditions of the Creative Commons Attribution (CC BY) license (https:// creativecommons.org/licenses/by/ $4.0 /)$.

\begin{abstract}
Bone regeneration is a complex process that is influenced by tissue interactions, inflammatory responses, and progenitor cells. Diseases, lifestyle, or multiple trauma can disturb fracture healing, which might result in prolonged healing duration or even failure. The current gold standard therapy in these cases are bone grafts. However, they are associated with several disadvantages, e.g., donor site morbidity and availability of appropriate material. Bone tissue engineering has been proposed as a promising alternative. The success of bone-tissue engineering depends on the administered cells, osteogenic differentiation, and secretome. Different stem cell types offer advantages and drawbacks in this field, while adipose-derived stem or stromal cells (ASCs) are in particular promising. They show high osteogenic potential, osteoinductive ability, and immunomodulation properties. Furthermore, they can be harvested through a noninvasive process in high numbers. ASCs can be induced into osteogenic lineage through bioactive molecules, i.e., growth factors and cytokines. Moreover, their secretome, in particular extracellular vesicles, has been linked to fracture healing. The aim of this review is a comprehensive overview of ASCs for bone regeneration and bone tissue engineering.
\end{abstract}

Keywords: mesenchymal stem cells; regenerative medicine; fracture healing; osteogenic differentiation; osteogenesis; mechanic stimuli

\section{Introduction}

Bone regeneration is a sophisticated process influenced by a variety of factors. In young healthy patients, bone tissue shows high self-repair abilities. However, systematic factors, such as an increased age, disease or obesity can negatively affect bone regeneration [1-3]. Large defects due to heavy trauma, multiple fracture, infection, or tumor resection, are also disruptive for proper tissue healing [4,5]. Notably, 5-10\% of all fracture healing is disturbed, might take months longer or is even impossible $[2,6]$.

The current gold standard for bone defect reconstruction is bone grafting where autologous bone tissue is transplanted to bridge the gap in the bone defect zone. The graft structure is similar to the original bone, which enables growth and regeneration. However, there are limitations to this therapy, such as donor site morbidity and availability of suitable autologous material [5].

A promising approach is bone tissue engineering, which has been successfully applied in a few clinical trials [7-10]. One approach is to transplant osteogenically induced stem cells into the bone defect zone, which then support the healing process. Within the fracture zone, the cells undergo further osteogenic differentiation, secretion of osteogenic factors, and recruitment of osteoblast progenitor cells. Stem cells can also be combined with allogeneic, alloplastic or xenogeneic scaffolds. These structures are seeded with the cells and support healing by their osteoinductive and/or osteoconductive properties [11]. 
Stem cells can be isolated from embryonic, fetal and adult tissue. Alternatively, cells are induced into the pluripotent stem-cell state: induced pluripotent stem (iPS) cells. Embryonic, fetal, or reprogrammed cells are associated with major safety, regulatory and ethical problems [12]. In contrast, adult stem cells can easily be isolated from a variety of tissues including adipose-derived stem or stromal cells (ASCs) from adipose tissue, with high osteoinductive and osteogenic potential [11]. These adult stem cells are called mesenchymal stem cells (MSCs). Beside ASCs, bone marrow mesenchymal stem cells (bmMSCs) are another type of MSCs, which also show the typical characteristics of all MSCs. Bone marrow biopsy allows isolation of bmMSCs, which is a procedure with risk of additional morbidity that provides only a low yield of cells, when compared to the surgical procedure for harvesting ASCs: ASCs can be easily harvested through noninvasive procedure and have a significantly higher yield of cells than that obtained for bmMSCs [13]. Moreover, ASCs have a higher proliferation capacity and more colony-forming units compared to bmMSCs $[14,15]$. Cell therapy requires high numbers of cells for successful application. This could require artificial cell expansion to reach sufficient numbers [16]. However, cell culture increases senescence with every passage, with the consequence of reduced proliferation, changes in morphology, which both could influence the cell function. bmMSCs are more susceptible to senescence and have a shorter life span then ASCs $[14,15]$.

Bone tissue engineering is a sophisticated process, in which there is an interplay between stem cell properties, osteogenic pathways and secretome. Here we review these concepts.

\section{Bone Regeneration}

Bone tissue is able to remodel and self-renew, which happens throughout a human's lifespan. Their extra-cellular matrix, which consists of water, minerals (e.g., hydroxyapatite, calcium fluoride, and calcium carbonate), and proteins (mostly type I collagen) [17], undergoes constant remodeling. Equilibrium is obtained by synthesizing osteoblasts and degradation from osteoclasts [3]. bmMSCs influence this through their secretome and their ability to develop into osteoblasts $[3,18]$.

\subsection{Fracture Healing}

Fracture healing can take place in two ways: primary healing requires that the fragments are in close contact and immobilized. This happens when a fracture is immediately treated after trauma. A small amount of granular tissue and callus forms between both fracture ends. The cutting cone, which consists of osteoclasts, creates zones between both ends, while osteoblasts interconnect these zones. The new bone is then formed and the fracture is closed $[2,19]$.

However, most fractures close through secondary healing, also called endochondral ossification. This process is divided into four stages: hematoma formation (days 1-5), soft callus formation (days 5-11), hard callus formation (days 11-28), and bone remodeling (day 28-months later) [2].

Trauma causes the fracture itself and additionally leads to rupture of blood vessels inside the bone, which creates a hematoma. The hematoma creates a clot inside the fracture, which induces the recruitment of immune cells, including macrophages, monocytes, and lymphocytes. These cells influence the subsequent process of osteogenesis [20,21]. They initiate and modulate the fracture healing process. In particular, macrophages are crucially involved in bone healing through their secretome [20,22] and by forming a layer above the osteoblast, which is called an osteomac [23]. The macrophages have different phenotypes, such as M1 (the so-called activated or proinflammatory phenotype) and M2 (the alternatively activated or anti-inflammatory phenotype), which are induced during different phases and, in turn, influence different processes of bone healing. The exact mechanisms and participations during bone tissue regeneration are not completely understood [24,25]. The M1 phenotype appears to support the inflammatory response and reduces regenerative osteogenic potential. Moreover, M2 phenotypes have pro-osteogenic 
effects though their secretome. Kang et al. [25] studied healing of rat calvaria defects and show that M2 secretomes support fracture healing. Furthermore, macrophage deficient mice have fewer MSCs in their bones, decrease bone mineralization and longer fracture healing time [22]. On the other hand, a high and prolonged inflammatory intensity impairs, or even completely inhibits, the tissue healing process [3].

In the second step, granulation tissue, which is rich in fibroin, develops inside the fracture. The growth factors secreted by immune cells include vascular endothelial growth factor (VEGF), which induces vascularization and the outgrowth of blood vessels. Moreover, MSCs are recruited to the fracture site, and they start to proliferate and differentiate into chondroblasts, osteoblasts, and fibroblasts. Chondroblasts help with the creation of a soft cartilage callus inside the fracture [2,19].

The soft cartilage callus is incrementally replaced by a hard bone callus during the subsequent days. This is accomplished by the collaboration of osteoblasts, osteoclasts, chondroclasts and chondroblasts. Vascularization also occurs deeper into the callus, thus facilitating MSCs to invaginate. This process, in turn, fosters the creation of a hard callus. Osteo-progenitor cells start the creation of woven bone from periosteal. At the end of this stage, the callus is completely replaced by bone tissue [2,19].

To complete the healing, the bone must be remodeled, which is achieved through the equilibrium of osteoclast resorption and osteoblast rebuilding. The remodeling aims to create compact bone at the center and lamellar bone at the edge. This process can take months to complete $[2,3,20]$.

\subsection{Impaired Bone Healing}

Fracture healing in $5-10 \%$ of patients can fail or be delayed for months [2,6], and this can either be caused by systemic risk factors, such as obesity, malnutrition, smoking, anemia, endocrine conditions, disease and aging [1-3] and/or local risk factors extensive fractures from massive trauma, multiple and open fractures, radiotherapy or infection [5].

Older people suffer from reduced bone mass and thus experience more frequent and severe bone fractures [3,26]. Moreover, their MSCs have a reduced commitment to osteogenic lineage and are primed for adipogenesis [27]. Studies have shown that several osteogenic transcription factors are reduced in older MSCs, including MAF bZIP transcription factor [28], Forkhead box P1 [29], and Core-binding factor $\beta$ [30]. Accordingly, fracture healing is impaired among the elderly, and recovery takes longer. In animal studies, older rats show less bone regeneration, reduced vascularization of their callus, less cartilage, and decreased ossification [31].

Diseases, such as diabetes type I and type II, osteoporosis, and osteogenesis imperfecta, are also a major factor in interrupted fracture healing [3]. Osteoporosis leads to less $\mathrm{Ca}^{2+}$ deposition in the bones, making the structure weaker. As such, trauma can result in larger fractures, which often require additional treatment [32]. The impact of osteoporosis on fracture healing has been disputed in conflicting studies [33,34].

Most cases of osteogenesis imperfecta are due to genetic mutation in collagen type I. The disease is associated with more brittle bones and more fractures. The healing of these fractures in many cases results in non-union, which often requires a longer healing time $[3,35,36]$.

Patients with diabetes generally show reduced bone regeneration. In $87 \%$ of cases, fractures need a longer healing period. These patients have a 3.4 times higher risk for complications [37]. Thereby, myostatin regulates bone formation, and blocking myostatin improves fracture healing in patients with type 2 diabetes [38]. Furthermore, diabetes is associated with advanced glycation end-products, which are proteins linked to aldose. These proteins can bind to the receptor of advanced glycation end products (RAGE) and lead to a proinflammatory response. They are also linked to an increased number of osteoclasts [37,39], reduce osteoblast ability for bone repair, and decreasing bone mineralization [40]. 
Moreover, fracture healing can be impaired through infections. Staphylococcus aureus is a common pathogen in healthcare settings and is often associated with soft tissue complications [41,42]. The pathogen is also responsible for $30-42 \%$ of all infections during bone healing, which can appear because of an open fracture, or bone fixation. Thereby, bone regeneration is disturbed, and antimicrobial therapy is necessary [43].

In an aging society where there is an increase in lifestyle diseases, such as diabetes, it is crucial to have efficient treatment for delayed or failed fracture healing. The method currently used is bone grafting.

\subsection{Interaction of Inflammatory and Bone Cells during the Fracture Healing and Bone Re-Generation-The Nrf2-Keap1 System}

In the mechanism of intractable fractures, oxidative stress is considered one of the main factors that interfere with fracture healing. Oxidative stress is generally caused by an imbalance between oxidation and reduction. During the early phase of fracture healing, reactive oxygen species (ROS) are generated under inflammatory and ischemic conditions [44]. However, the influence of ROS can be normally restricted by protective antioxidant enzymes, capable of stabilizing or deactivating free radicals before cellular components are attacked [45-47]. On the other hand, excessive oxidative stress potentially can occur after the fracture in patients with underlying diseases that inherently expose to oxidative stress, as well as disruptive or compound fractures [45]. Excessive ROS can lead to chronic inflammation [48], decrease in osteoblast function and differentiation $[49,50]$, whereas they can activate bone resorption through elevating osteoclast differentiation and function [51]. Thus, these modifications of bone metabolism by oxidative stress affect bone remodeling and regeneration [52].

The Nuclear factor erythroid 2-related factor 2 (Nrf2)-Kelch-like erythroid cell-derived protein with cap ' $n$ ' collar homology-associated protein 1 (Keap1) system plays an important role in the regulation of the biological response to oxidative stress. In the basal condition, Nrf2 is regulated by the stress sensor Keap1. Under conditions of oxidative stress, stabilized Nrf2 is translocated into the nucleus where it binds to antioxidant-response elements (ARE) in the promoter regions of target genes, resulting in the activation of a variety of antioxidant genes $[53,54]$. Recently, attention has focused on the role of Nrf2 in fracture healing process. A previous report showed that Nrf2 deficiency decreased fracture callus by using Nrf2-knockout (KO) mice [55]. Moreover, Nrf2 can be involved in the control of excessive inflammatory responses [56], the promotion of osteogenesis in MSCs, and angiogenesis through VEGF expression [57], in early phase of fracture healing. In the remodeling phase, Nrf2 also regulates the balance of bone metabolism by suppressing oxidative stressinduced osteoclastogenesis [58]. In light of bone tissue engineering, it is expected that Nrf2 would be a future therapeutic strategy for fracture healing or bone regeneration in patients with intrinsic oxidative stress such as diabetes type II or osteoporosis [45].

\section{Bone Grafts}

The current gold standard to treat delayed or impaired bone recovery as well as for bone defects is the transplantation of autologous or allogeneic bone grafts [11,20]. Autografts are bone tissues from distant donor sites of the same patient (Figures 1 and 2). They do not induce immunogenic reaction and have osteoinductive effects, e.g., by releasing growth factors. Osteoblast progenitor cells in the graft provide the tissue with osteogenic properties. However, the graft is obtained in another operation, which presents an additional risk of morbidity for the patients. Moreover, it is not always possible to harvest adequate material [20]. Meanwhile, allografts are a decellularized matrix and are obtained from other patients or corpses. Decellularization is accomplished though irradiation or freeze drying [11]. Allografts have a similar bone structure and extracellular matrix as the original bone. Their incorporation is lower compared to autografts [21]; they also present a risk of transmitting infections [59]. Furthermore, they can induce an immune response and can have a high batch variation [20]. 


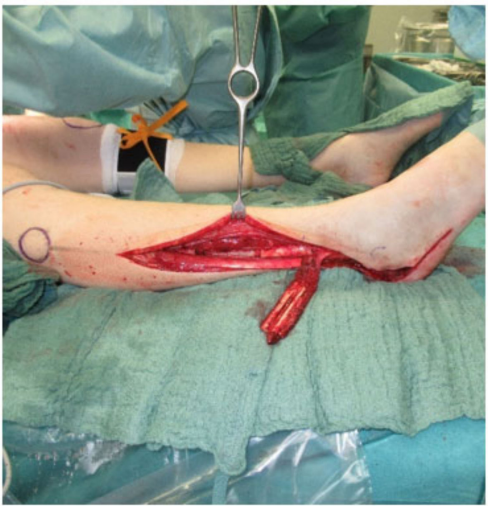

a

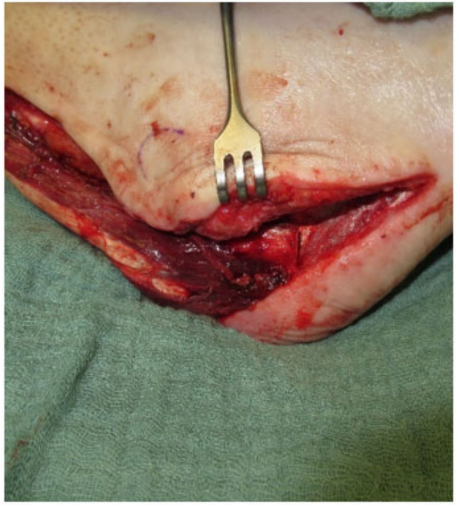

b

Figure 1. Pedicled autologous bone graft transplantation. Distally pedicled peroneus brevis muscle flap with a fibula segment is harvested from the right lower leg. The transplant is used for reconstruction of a calcaneus defects with a soft tissue defect (a). Distally pedicled peroneus brevis muscle flap is transferred into right calcaneal bone defect (b).

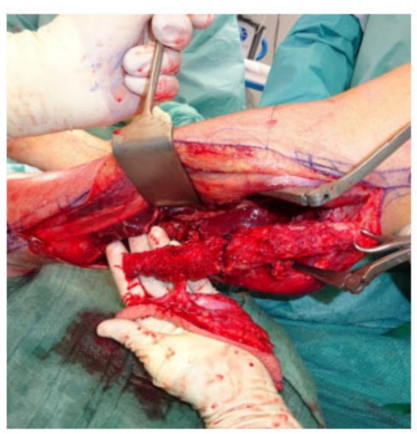

a

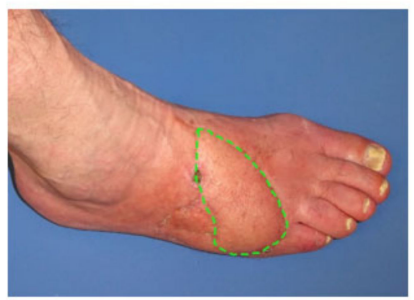

C

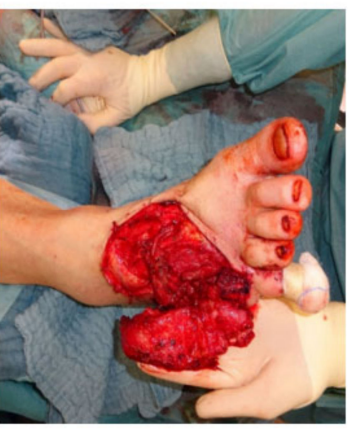

b

Figure 2. Free microvascular autologous bone transplantation for metatarsal defect. A free fibula transplant with a single-perforator based skin island is harvested from the left lower leg (a). The osteocutaneous flap is transplanted into the defect to reconstruct the fifth metatarsal bone of the right foot (vascular anastomosis is performed by connecting the flaps pedicle, i.e., the left fibular artery, to the anterior tibial artery of the right foot in an end-to-side manner) (b). The skin island (green dotted line) is twisted 90 degrees and is subsequently used to closes the concomitant soft tissue defect (c).

Bone grafting is a well-established approach that is used in over 500,000 cases every year in the USA [20,60]. Nevertheless, bone grafts have disadvantages, as described above. In order to avoid such risk factors, alternative approaches are currently under experimental and/or clinical investigation.

\section{Cell Therapy}

Bone tissue engineering is a promising approach for fracture healing, which offers high regeneration capability and biocompatibility. This technique requires stem cells, which can be isolated from various sources [12]. 


\subsection{Embryonic- and Induced Pluripotent Stem Cells}

Embryonic stem cells (ESCs) are obtained from the inner cell mass of blastocysts. As pluripotent stem cells, they can differentiate into cells of all three germ lines. ESCs have several advantages as a source for bone tissue engineering: self-renewal ability, pluripotency, high genome stability after multiple passaging [61], and sufficient osteogenic potential [62]. However, ESCs availability can be problematic due to low access of available tissue and ethical concerns [12]. Furthermore, undifferentiated ESCs can be carcinogenic and form teratoma, which are tumor tissues with cells from all three lineages [63]. Therefore, ESCs must be cleared of all undifferentiated cells before usage in tissue engineering [13], which is a safety concern.

Overexpression of the genes Oct4/3, Sox2, Klf4, and c-Myc in adult cells leads to the creation of iPSC. Shinya Yamanaka et al. [64] were the first group to create iPSC in 2006 from mice fibroblasts. Human iPSCs were created one year later also from fibroblasts [65]. iPSCs are pluripotent cells like ESCs, but they bypass the ethical concerns surrounding ESCs. The osteogenic capacity of iPSCs is similar to that of ESCs [66] and they have been successfully used for bone tissue engineering in animal models $[67,68]$. The method of creation from iPSCs has given rise to some concerns that they may be carcinogenic $[65,69]$. Additionally, the transcriptome of iPSCs is similar to cancer cells $[12,70]$. One method to reduce this is to differentiate iPSCs before usage [71]. During this process, no contamination of undifferentiated cells should remain.

\subsection{Adult Stem Cells}

Friendenstein et al. [72] were the first group in 1970, that showed that adult stem cells have multilineage potential and can be induced into osteogenesis [72]. These cells have immunomodulatory and regenerative capabilities [12]. They are commonly referred to asMSCs, but they were pushed for a name that better reflects their role and origin. Thus, "tissue-specific progenitor cells" and "medicinal signaling cells" have been proposed [73,74]. MSCs are a heterogeneous mix of committed stem- and progenitor cells [75]. The International Society for Cellular Therapy has set four criteria for defining MSCs [76]. These include adherent cells in a standard cell culture, which can differentiate into osteogenic, chondrogenic and adipogenic lineages. Moreover, MSCs must express CD73, CD90 and CD105. Furthermore, they should lack expression of CD11b, CD14, CD19, CD34, CD45, CD79 $\alpha$ and the HLA-DR surface marker [76].

MSCs are derived from perivascular niche and can be found in almost all tissues with vascularization [12,77]. Therefore MSCs can be harvested from skeletal muscle [78], umbilical cord [79], skin [80], dental pulp [81], bone marrow [82], and adipose tissue [83,84].

Bone marrow comprises hematopoietic cells, different adipose stem cells, stromal cells and bone marrow MSCs (bmMSCs) [85,86], and many studies have focused on this reliable source of MSCs. bmMSCs have high osteogenic differentiation and proliferation potential and a low risk of immunogenicity. Therefore, bmMSCs have often been used for bone tissue engineering. Li et al. [87] used bmMSCs for the recovery of orbital defects in rats. Jingying et al. [88] repaired calvarial defects in rabbits with bmMSCs. However, the extraction of bone marrow is an invasive procedure and can be dangerous to patients. Moreover, the concentration of cells per $\mathrm{mL}$ bone marrow aspirate is only $0.001-0.01 \%$ [13], necessitating the intensive use of cell culture and growth factors to obtain sufficient cells for therapeutic approaches, such as bone regeneration. The high heterogeneity of bmMSCs is another problem: bmMSCs become homogenous only after several passages [89]. Heterogeneous bmMSCs have reduced osteogenic differentiation and different morphologies $[90,91]$.

\subsection{Adipose-Derived Stem or Stromal Cells}

In addition to bmMSCs, ASCs are another group of MSCs used in many studies for bone tissue engineering [11]. They are characterized to be positive for the surface markers CD13, CD29, CD44, CD73, CD90 and CD105. Moreover, ASCs should lack CD31, CD45 and CD235a. They can be distinguished from bmMSCs by the markers CD106 and CD36; 
ASCs are positive for the first one and negative for the latter, vice versa for bmMSC [92]. Both MSCs groups origin from different stem cell "niches", which might account for the differences in their differentiation potential. Thus, ASCs are more primed to develop into adipocytes, and bmMSCs into ostoblasts, although the osteogenic potential of ASCs and bmMSCs is disputed. The majority of studies found stronger osteogenic capacity in bmMSC [93-96], but some could not find any difference $[14,97,98]$. Especially due to the differences in the differentiation potential and also the secretory activity of the cells, the International Society for Cellular Therapy (ISCT) have proposed the nomenclature of ASCs vs. bmMSCs, to highlight the difference between both groups [92].

ASCs can be harvested through liposuction from adipose tissue, a safe and minimally invasive procedure. Moreover, lipoaspirate has a high yield of ASCs at $2 \%$ and over $10^{7}$ ASCs can be isolated from $300 \mathrm{~mL}$ lipoaspirate $[99,100]$. ASCs also provide high osteogenic potential. The secretome has beneficial effects, as it recruits other progenitor cells and can induce osteogenic differentiation [5,101]. Allogenic ASC usage is theoretically possible because they have a low risk of immunogenicity, since ASCs have a low number of MHC class II molecules, immune cell stimulation factors CD80, CD86 and CD40 [102,103], and release an immunosuppressive secretome [13].

ASCs are perivascular progenitor cells $[11,104]$ derived from the stromal vascular fraction (SVF), which additionally consists of endothelial cells, fibroblasts, pericytes, monocyte, macrophages, lymphocytes, blood-derived cells, vascular smooth muscle cells, and preadipocytes [105]. Depending on different factors, including the age of the patient, donor site, and type of fat tissue, the SVF contains different numbers of ASCs [106,107]. Moreover, freshly isolated ASCs can have heterogeneity in their lineage potential. Thus, fresh adherent ASCs are composed of $21 \%$ tri-, $31 \%$ bi-, $29 \%$ unipotent cells and $19 \%$ without lineage potential. ASCs become more homogeneous after passaging and reducing the remaining stromal cells [108].

ASCs are often cultivated in a basal medium with $10 \%$ fetal calf serum (FCS) [5]. Some researchers add supplements, such as fibroblast growth factor 2 (FGF-2) or transforming growth factor (TGF- $\beta$ ) [109]. As FCS is a xenogeneic substance, autologous serum was proposed as an alternative nutrient source. The nutrient source shows only minor impact on osteogenic differentiation of ASCs [110], which indicates that autologous serum could be a viable alternative. Comparing studies on ASCs can be difficult since protocols are often not standardized and this can influence the properties of the ASCs $[111,112]$.

\section{Osteogenic Stem Cell Differentiation through Bioactive Factors}

\subsection{ASC Osteogenic Differentiation}

ASCs have a multilineage potential of differentiation and can e.g., follow an adipogenic, chondrogenic or osteogenic fate. Each lineage has major regulators that determine the fate of the cells. For osteogenesis, these are Runx2 and Osterix (Sp7 transcription factor) $[113,114]$. Regulation involves a complex network and several signaling pathways control osteogenic differentiation, among others bone morphogenetic protein (BMP)- [115], Notch- [116], Wnt- [112] and Hedgehog-signaling [117]. The Wnt signaling pathway is key as it serves as governor between ASC lineages. It channels ASCs away from adipogenic or chondrogenic lineage to osteogenic differentiation by increasing Runx2 and Osterix [118].

Wnt signaling acts over two pathways: via a canonical $\beta$-catenin pathway (Figure 3) and one via a noncanonical pathway $[112,119]$. $\beta$-catenin is a pro-osteogenic transcription factor. However, unstimulated conditions lead to the phosphorylation of $\beta$-catenin by a removal-complex, which leads to the proteolytic depletion of $\beta$-catenin. The pathway starts when Wnt binds to the Fizzled receptor, which is supported by low density lipoprotein receptor related protein 5/6 (LRP5/6). The signal leads to the disheveled proteins (DSH) binding to the removal complex and attaching it to the receptor. The complex cannot mark $\beta$-catenin for degrading and it moves to the nucleus. There, $\beta$-catenin, lymphoid enhancer binding factor 1 and T-cell factor1,3,4 (TCF1,3,4) form a complex, which supports expression of osteogenic genes, such as Osterix and RUNX2 [120]. In the noncanonical pathway, Wnt 
binds to the receptor tyrosine kinase-like orphan receptor-1 and 2 (ROR1/ROR2), which leads to the activation of a G-protein, whereby the intracellular $\mathrm{Ca}^{2+}$ from the endoplasmic reticulum is released [121]. $\mathrm{Ca}^{2+}$ acts as second messenger and is very important for several signaling pathways; including osteoblast proliferation [122].

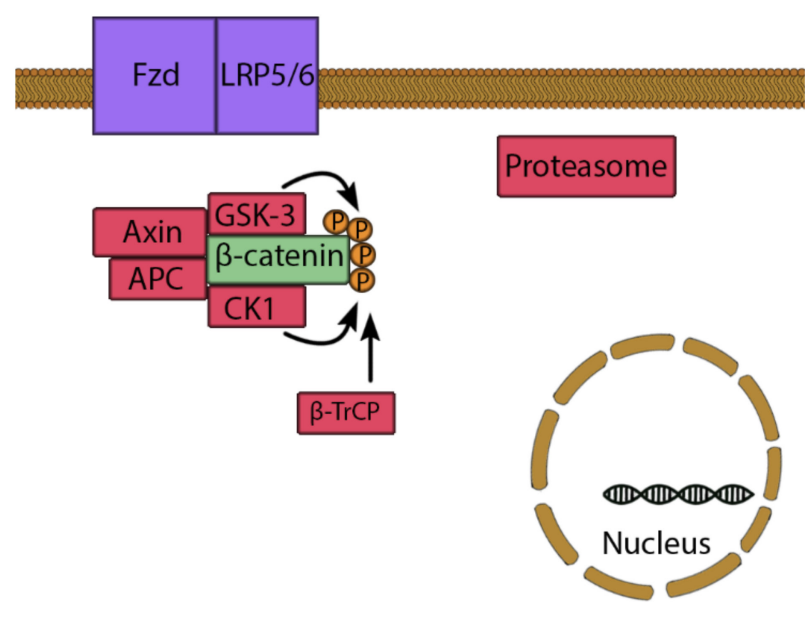

Cytoplasm

(a)

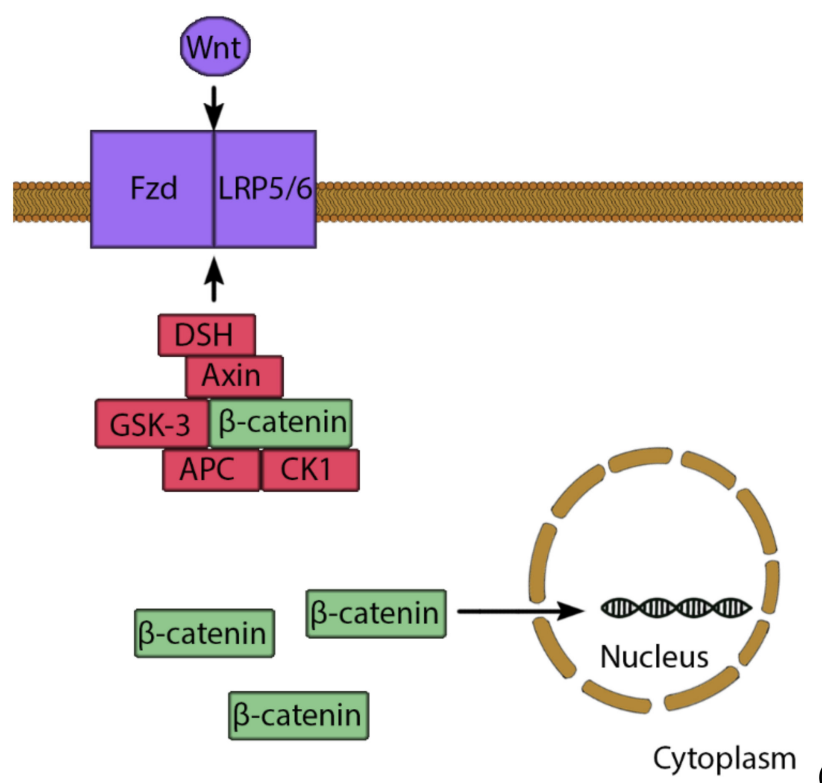

(c)

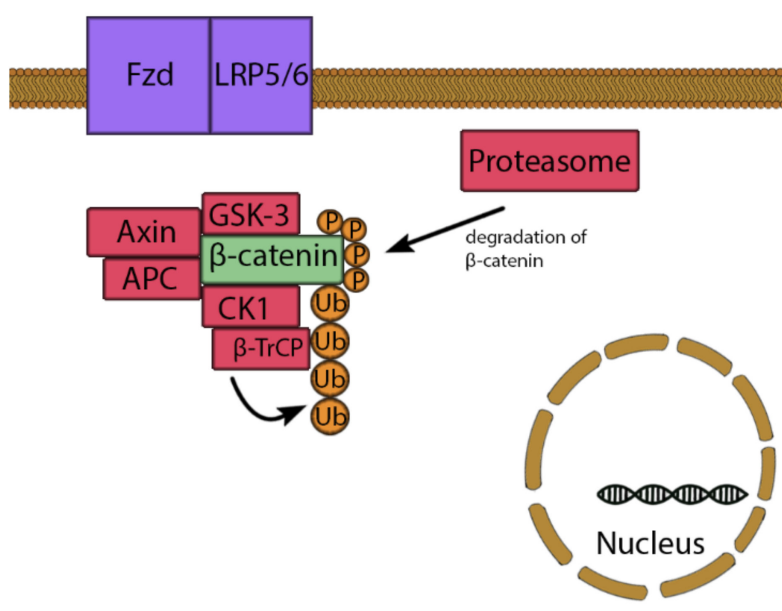

Cytoplasm

(b)

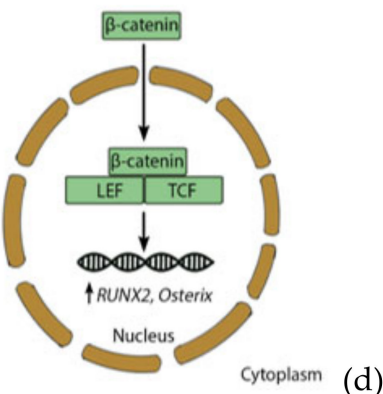

Figure 3. Wnt/ $\beta$-catenin pathway. Under basal conditions, $\beta$-catenin is bound by a removal complex consisting of Axin, GSK-3, APC and CK1 (a). GSK-3 and CK-1 marked $\beta$-catenin though phosphorylation, which recruits $\beta$-TrCP. $\beta$-TrCP leads to ubiquitination and degradation of $\beta$-catenin $(\mathbf{b})$. However, stimulation of Wnt leads to activation of disheveled proteins (DSH), which binds the removal complex to the receptor. Therefore, $\beta$-catenin is not degraded and can enter the nucleus (c), where it forms a complex with TCF and LEF transcription factors. This complex induces expression of e.g., RUNX2 and Osterix, leading to osteogenic differentiation (d).

ASCs for bone regeneration therapy can be induced into the osteogenic lineage using a differentiation medium comprising dexamethasone, beta-glycerophosphate and ascorbic acid [123]. Dexamethasone was investigated to decrease necrosis, increase proliferation and stimulate osteogenesis, in particular through the Wnt/ $\beta$-catenin pathway, which increases among others the osteogenic regulators Runx2 and Osterix. Moreover, dexamethasone upregulates Runx2 activity. Beta-glycerophosphate supports osteogenesis by acting as a phosphate source for several reactions, and ascorbic acid increases production and secretion of pro-collagen $[112,123]$. 


\subsection{Supplementary Substances as Osteogenic Stimuli}

Supplementary substances added to the medium can accelerate and/or increase overall potential for osteogenic differentiation. Furthermore, ASCs harvested from patients with systemic conditions such as osteoporosis, or aging, may suffer from a reduced inherent potential for bone tissue engineering [124,125], which makes therapeutic treatment necessary.

Growth factors can be added to increase osteogenic potential, proliferation, vascularization, migration and differentiation of progenitor cells [11]. The BMPs are a major pro-osteogenic growth factor group [126]. There are 16 different types of BMPs (BMP-1-16), which belong to the TGF family [127]. The BMP signaling pathway starts by binding to Ser/Thr kinase receptors, which influence the cells via multiple pathways. The most potent induction acts via the Smad transcription factor (Figure 4), whereby binding of BMP-2 or -3 activates the receptor, which phosphorylates the regulatory complex of Smad1/5/8. This allows the attachment of Smad4 to the complex, which moves to the nucleus to increase expression of RUNX2 and Osterix [112,115]. Moreover, BMP influences the cell via the messenger molecules: extracellular signaling-regulated kinase (ERK), c-Jun $\mathrm{N}$-terminal kinase (JNK), p38 and mitogen-activated protein kinase (MAPK), which all influence osteogenesis [112,116]. BMP-2 has been approved by the US Food and Drug Administration for clinical usage in 2003 and has been used successfully in clinical trials for spine fusion and tibial fractures $[109,128]$.

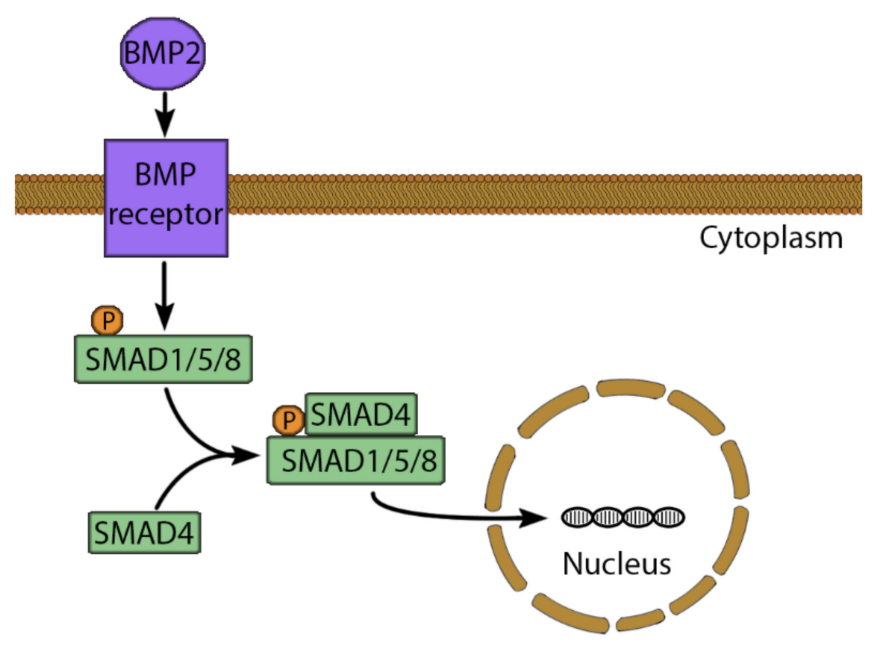

Figure 4. The BMP-2 signaling pathway. BMP-2 binds to a serine/threonine kinase receptor, leading to phosphorylation and activation of SMAD1/5/8. Therefore, SMAD4 can bind to SMAD1/5/8 to form a complex. This complex moves to the nucleus and binds to a specific SMAD binding element. This stimulates the expression of osteogenic genes such as RUNX2 and Osterix.

Several studies have used a wide variety of substrates to increase the osteogenic potential of ASCs, such as vitamin D3 [129], alendronate [130], selenium [131], and platelet-rich plasma [132]. Figure 5 shows the influence that substrate or mechanical stimuli have on osteogenic signaling pathways of BMP-2 and Wnt. Other factors involve the inflammatory response, which is the first step of fracture healing (described above). Lipid polysaccharide (LPS) from the membrane of Gram-negative bacteria lead to a proinflammatory immune response and can affect ASCs through the toll-like receptor 4 (TLR4). This receptor activates the NF- $\mathrm{kB}$ pathway [133], which influences a variety of cell functions, including proliferation, apoptosis, inflammatory responses, and osteogenic differentiation [134,135]. Peters et al. [136] have shown in in vitro ASCs studies that LPS increases the osteogenic markers of extracellular calcium content and alkaline phosphatase (ALP) activity. Moreover, the endocannabinoid system influences a wide variety of systems in nearly all tissues, including modulation of the inflammatory response, cell stress, wound healing $[137,138]$ 
and bone formation [139]. In ASC cell culture, some endocannabinoids could improve osteogenic differentiation, including plant-derived cannabidiol (CBD) [140] and endogenous $\mathrm{N}$-arachidonoylethanolamine (AEA) [141]. In addition, the combination of LPS and CBD treatment on ASCs seems beneficial, since LPS alone increases cellular stress, and CBD can stop this [137].

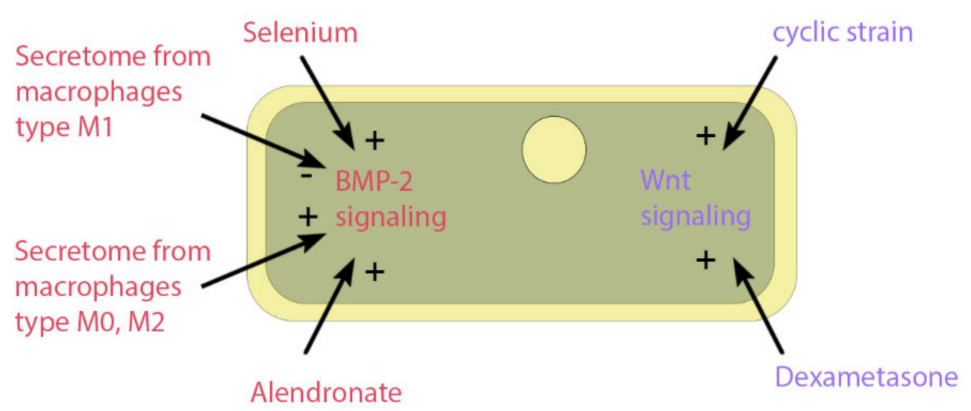

Figure 5. Impact on osteogenic signaling pathways. The figure shows the impact of pharmacological or mechanical stimuli on the osteogenic signaling pathways of BMP-2 or Wnt. The factors include selenium particles, secretome from different phenotypes of macrophages, the drug alendronate, the osteogenic differentiation medium component dexamethasone, and dynamic cell culture through a cyclic strain.

\subsection{Mechanical Stimuli on Osteogenic Differentiation}

Regulation of MSCs during embryonic development and fracture healing is influenced by mechanical stimulation. Extrinsic mechanical forces can be used to mimic these effects and also support osteogenic differentiation of cultured ASCs [142].

One example is tensile strain through uniaxial or equiaxial stretching, where cells are seeded with osteogenic differentiation medium in a chamber made of flexible material, such as polydimethylsiloxane (PDMS). The combination of biochemical and mechanical stimulation increases the osteogenic differentiation, when compared to one factor applied solely. Furthermore, stretching increases focal adhesion and the amount of actin in the cytoskeleton $[143,144]$. This mechanical stimulus has been shown to increase the Wnt signaling, which induces cellular osteogenic differentiation [112]. Mechanical strain also impacts oxidative stress regulation through the Nrf2/ARE pathway. A study with MSCs from dental pulp shows that cyclic strain increases ROS and the inflammatory response. This activates Nrf2/ ARE signaling, increasing the expression of antioxidant enzymes [145,146].

Furthermore, vibration loading is used to create a dynamic input onto ASCs in vitro. In this approach, the cells are seeded on e.g., a petri dishes and loaded onto a platform that can vibrate at specific frequencies. Vibration loading of ASCs results in an increase of osteogenic markers, including ALP activity, collagen levels, and the $\mathrm{Ca}^{2+}$ deposition in the ECM. Moreover, vibration loading inhibits adipogenic differentiation [147,148].

Flow intensity over the cells also impacts ASCs, which has been investigated in 2D and 3D culture. Tjabringa et al. [149] studied pulsating fluid flow in 2D; the stimulus was applied for one hour and the gene expression of RUNX2 levels increased while secreted phosphoprotein 1 (SPP1) (gen of osteopontin) stayed unaffected. Runx2 is associated with the early phase of osteogenesis and osteopontin with later stages. Therefore, it has been proposed that a pulsating fluid flow may induce the early stages of osteogenesis [150]. Fröhlich et al. [151] seeded ASCs on a decellularized bone graft and used fluid flow in a bioreactor to support osteogenesis. Perfusion increase mineralization compared to motionless culture after 5 weeks. However, in 3D culture, it is unclear whether the effect is a result of the mechanical stimuli or the better cell culture conditions (e.g., gas- and nutrition exchange and dispensation of cells) [142].

Electromagnetic fields that were applied as a direct or alternating current between 2 and $123 \mathrm{~Hz}$ affect osteogenesis of ASCs. Runx2, ALP activity, collagen I, and osteopotin increased $[112,152]$. The electric signaling is associated with intracellular $\mathrm{Ca}^{2+}$ release 
from the endoplasmic reticulum, which is of relevance for several physiologic processes, including osteogenesis [112].

\section{Secretome and ASCs in Crosstalk during Bone Regeneration \\ 6.1. The ASC Secretome}

Fracture healing is a complex process, which is influenced by the crosstalk of surrounding tissues and related wound factors. Seeding ASCs in the fracture support bone recovery. They exert paracrine effects through the release of soluble factors (e.g., cytokines and growth factors) and small extracellular vesicles (EVs). The ASC secretome influences the surrounding tissue in multiple ways. It supports angiogenic, osteogenic differentiation and progenitor cells are recruited to the fracture site. Furthermore, ASCs have immunomodulation properties $[5,101]$. It has been shown that they interact with the innate immune system and reduce the number of B-cells in a fracture [153].

\subsection{Extracellular Vesicle from ASCs}

EVs also influence stem and progenitor cells in the tissue crosstalk. They can be found in nearly all tissues and have received more attention in recent years. The vesicles consist of a lipid bilayer surrounding the loaded cargo. They regulate many processes and often have pleiotropic effects because they are very heterogeneous in nature [154]. EVs are involved in the horizontal transfer of mRNA, miRNA, other noncoding RNA, proteins, lipids [155], and mitochondrial DNA [156]. For cell therapy and tissue engineering, two types of EVs are important: microvesicles and exosomes. Compared to exosomes, microvesicles are larger, measuring 100-1000 nm. They are created through an outward budding of the cellular membrane, which is regulated by small GTPase [157]. On their surface, microvesicles contain selectine and integrine as markers [158]. Exosomes are 30-100 nm in size and are created at the endosome. They bud from the endosomal membrane into the lumen, which then creates the multivesicular endosome. EVs are released when the multivesicular endosome fuses with the cellular membrane [159]. Various markers, such as CD9, CD63, CD81, HSC70, ALIX, and flotillin-1 can be used to detect exosomes [160]. EVs influence tissue crosstalk through surface markers, such as membrane molecules [161] and their cargo-like regulatory RNA and factors of signal pathways [158]. It has been shown that EVs can act directly and bind to specific cells [162].

EVs are relevant to bone regeneration. In one study, Li et al. [163] found that embedded EVs from ASCs in a scaffold increase healing after six weeks. This study was conducted in a mouse model with a calvarial defect. EVs have osteogenic effects through influencing the phosphatidylinositol 3-kinase/protein kinase B (PI3K/AKT) signaling pathway [164] and the miRNA196a [165]. Moreover, they are involved in the recruitment of MSCs toward a fracture [166,167]. EVs have proangiogenic effect [168] and pro/anti-inflammatory effects [169]. However, the regulatory influence of EVs is not fully understood; it seems to depend on specific tissues and is very dependent on other factors [170]. For example, Zhu et al. [171] found that diabetes type 1 reduces the osteogenic effects of EVs.

\section{Preclinical Application}

In vitro studies facilitate a deeper understanding of the fundamental mechanics of cells, such as signaling pathways and possible inducing and/or supportive stimuli. However, the systematic interplay of various factors necessitates in vivo studies to acquire comprehensive results regarding the use of ASCs for bone tissue engineering [5,172].

ASCs can be directly injected into a fracture site or seeded onto an appropriate scaffold, which provides mechanical stability and protection for the cells. Furthermore, it can mimic the biophysical signals from the extracellular matrix, which can support osteogenic differentiation. The scaffold offers binding sites for the cells and space for calcium deposits. Thus, the size and connectivity of pores play an important role for artificial bone tissue engineering. The choice of pore size and stiffness of the structure is a compromise. Wider pores allow the migration of cells, greater secretion of bone material, and easy vascular- 
ization. However, they also reduce the surface for cell attachment. Thus, a wide variation in pore size is possible, depending on the scaffold material [11,109]. Besides pore size, integrating blood vessels into the scaffold is another strategy to increase vascularization. The arteriovenous loop (AV-loop) model is such a strategy and was shown to improve intrinsic vascularization [173-175].

A range of materials is available for the bone tissue engineering scaffolds, which are revised in [11], including ceramide, e.g. hydroxyapatite (HA), coralline-derived hydroxyapatite (cHA), $\beta$-tricalcium phosphate ( $\beta$-TCP) $[173,176,177]$, bioglasses [178], synthetic or biological polymers, e.g. collagen, fibrin [179], fibronectin [180], polylactic acid (PLA) [180], and poly lactic-co-glycolic acid (PLGA) $[130,181]$ and a combination of multiple materials $[182,183]$. Combinations of different materials can support osteogenic differentiation. An example is PLA scaffolds mixed with mineral substrates of dicalcium phosphate dihydrate or hydraulic calcium silicate [184].

Numerous preclinical studies have examined ASC for bone tissue engineering (Table 1). These studies should show which additional factor and scaffolds can be transferred to a in vivo model. The goal would be to reduce the necessity for additional factors and still provide sufficient osteogenic potential. This would facilitate the clinical application. Today, US Food and Drug Administration permits the addition of the growth factors BMP-2 and PDGF-BB (platelet-derived growth factor $\mathrm{BB}$ ) as bioactive molecules for bone tissue engineering $[128,185,186]$.

Table 1. Preclinical studies of ASCs as tool for bone tissue engineering.

\begin{tabular}{|c|c|c|c|c|}
\hline $\begin{array}{l}\text { Experimental } \\
\text { Model }\end{array}$ & Animal & Scaffold & Addition & Reference \\
\hline Calvarial defect & Rat & PLGA & Alendronate & [130] \\
\hline Calvarial defect & Mouse & HA/PLGA & rhBMP-2 & [183] \\
\hline Calvarial defect & Rat & $\beta-\mathrm{TCP}$ & miRNA-31 vector & [177] \\
\hline Calvarial defect & Mouse & PLGA & $\begin{array}{l}\text { Scaffold coated with } \\
\text { polydopamine and } \\
\text { immobilized rhBMP-2 }\end{array}$ & [181] \\
\hline Calvarial defect & Mouse & PLGA & $\begin{array}{l}B M P-2 \text { and } m i R-148 b \\
\text { vector }\end{array}$ & [188] \\
\hline Calvarial defect & Rat & PLGA & $\begin{array}{l}\text { Low power laser } \\
\text { irradiation }\end{array}$ & [189] \\
\hline Skull defect & Rabbit & PLA & $\begin{array}{l}\text { Scaffold coated } \\
\text { fibronectin }\end{array}$ & [180] \\
\hline Ulnar defect & Minipigs & $\begin{array}{c}\text { Decellular bone } \\
\text { graft }\end{array}$ & $\begin{array}{l}\text { rhBMP-2 and } r h V E G F \\
\text { vector }\end{array}$ & [190] \\
\hline $\begin{array}{l}\text { Vertebral bone } \\
\text { void defect }\end{array}$ & Rat & Fibrin gel & rhBMP-6 vector & [191] \\
\hline Femoral defect & Rat & $\beta-\mathrm{TCP}$ & $\begin{array}{l}B M P-2 \text { and } B M P-7 \\
\text { vector }\end{array}$ & [192] \\
\hline Femoral defect & Mouse & - & $b F G F$ vector & [187] \\
\hline AV-loop & Rat & HA granules & $\begin{array}{l}\text { Combination of ASCs } \\
\text { and human umbilical } \\
\text { vein endothelial cells }\end{array}$ & [173] \\
\hline
\end{tabular}

Comparability of the studies is difficult since various markers, measurements and time points have been used. Therefore, it would be helpful to utilize more uniform protocols. The ISCT has proposed that osteogenesis of ASCs could be measured by activity and/or expression of specific markers like alkaline phosphatase, osterix, osteocalcin, runx2 and bone sialoprotein [92]. 
Penington et al. [180] compared undifferentiated ASCs vs. ASCs in osteogenic lineage for the recovery of a skull defect in rabbits. Both cell types were seeded on a PLA/fibronectin scaffold and osteogenically determined ASCs demonstrate greater bone regeneration at six weeks after implantation. Ko et al. [181] studied a new method of immobilized growth factors in scaffolds, which then were gradually released. Therefore, a layer of dopamine was placed on a PLGA scaffold and then BMP-2 was attached via a catechol reaction. This method was applied to a calvarial defect and increased the osteogenic differentiation of ASCs when introduced inside a bone defect. Zhang et al. [187] modified ASCs with vectors to increase $b F G F$ expression and injected them into femoral fractures of mice. These transfections led to an increase in growth factor secretion (VEGF), angiogenesis, callus mineralization, and bone formation. Wang et al. [130] treated a calvarial defect in rats with ASCs seeded on a PLGA scaffold and alendronate. Alendronate was injected into the injury and increased bone regeneration after 8-12 weeks. Deng et al. [177] transfected ASCs with an miRNA-31 lentiviral vector. A rat calvarial defect was treated with a $\beta$-TCP scaffold seeded with these cells. The transfected cells increased healing, bone volume, and mineralization.

\section{Discussion}

Bone regeneration after fracture can be delayed or even fail due to age, disease, or extensive damage [2]. This is characterized by a deficit of bone remodeling and regeneration. It is often associated with a lack of stem cell recruitment, slow proliferation, low growth factor levels, and a prolonged inflammatory response [193].

Therefore, ASC-based cell therapy could be a new treatment. Currently, the topic is attracting much interest, including many publications and clinical trials. A search of clinical trials on www.clinicaltrials.gov (accessed on 17.03.2021) for adipose stem cells and bone shows 22 results. In this broad discussion, our goal was to show the interplay of the cellular and molecular properties of ASCs as tools for bone regeneration. We had a special emphasis on the in vivo translation. Thereby, we aim to show that ASC-based therapy is promising and could replace the current gold standard of bone grafts [20].

For treatment, adipose tissue is harvested through a noninvasive method. ASCs are isolated and receive optional osteogenic stimulation. Afterwards, they are implanted into the fracture. The role of ASCs is to support bone regeneration. They have osteogenic differentiation potential, immunomodulation abilities and can recruit further MSCs towards the fracture. Moreover, the ASCs' secretome facilitates bone regeneration. It contains growth factors, cytokines and EVs. These substrates include proangiogenic (e.g., VEGF) and pro-osteogenic (e.g., BMP-2) factors [5,158]. This shows that ASCs are a promising tool to deal with a prolonged or failed bone regeneration process, which has been applied in clinical use [7-10]. However, ASCs are far from an established method in clinical routine.

Osteogenic differentiation is a complex system involving multiple pathways. The secretome of ASCs and surrounding bone tissues significantly impact differentiation, and further studies are necessary to fully understand their mutual influence. Additionally, new ways to increase the osteogenic potential of ASCs could be beneficial for treatment. In our opinion, scaffolds coated with growth factors with a controlled release of these factors are particularly interesting [181]. They allow the local administration of osteogenic factors over time. This could help reducing side effects caused by systematic application and would promote the approval of addition factors for bone tissue engineering. Further studies can help bring bone tissue engineering into clinical daily routine.

Author Contributions: W.M. and Y.K. wrote the draft; J.P.B., T.P., R.G., T.R., edited and finalized the manuscript. All authors have read and agreed to the published version of the manuscript.

Funding: This research received no external funding.

Institutional Review Board Statement: Not applicable.

Informed Consent Statement: Not applicable. 


\section{Data Availability Statement: Not applicable.}

Conflicts of Interest: The authors declare no conflict of interest.

\section{References}

1. Karpouzos, A.; Diamantis, E.; Farmaki, P.; Savvanis, S.; Troupis, T. Nutritional Aspects of Bone Health and Fracture Healing. J. Osteoporos. 2017, 2017, 4218472. [CrossRef]

2. Sheen, J.R.; Garla, V.V. Fracture healing overview. In StatPearls; StatPearls Publishing: Treasure Island, FL, USA, 2020.

3. Simpson, C.R.; Kelly, H.M.; Murphy, C.M. Synergistic Use of Biomaterials and Licensed Therapeutics to Manipulate Bone Remodelling and Promote Non-Union Fracture Repair. Adv. Drug Deliv. Rev. 2020, 160, 212-233. [CrossRef]

4. Gómez-Barrena, E.; Rosset, P.; Lozano, D.; Stanovici, J.; Ermthaller, C.; Gerbhard, F. Bone Fracture Healing: Cell Therapy in Delayed Unions and Nonunions. Bone 2015, 70, 93-101. [CrossRef]

5. Barba, M.; Di Taranto, G.; Lattanzi, W. Adipose-Derived Stem Cell Therapies for Bone Regeneration. Expert Opin. Biol. Ther. 2017, 17, 677-689. [CrossRef]

6. Mills, L.A.; Aitken, S.A.; Simpson, A.H.R.W. The Risk of Non-Union per Fracture: Current Myths and Revised Figures from a Population of over 4 Million Adults. Acta Orthop. 2017, 88, 434-439. [CrossRef]

7. Lendeckel, S.; Jödicke, A.; Christophis, P.; Heidinger, K.; Wolff, J.; Fraser, J.K.; Hedrick, M.H.; Berthold, L.; Howaldt, H.-P. Autologous Stem Cells (Adipose) and Fibrin Glue Used to Treat Widespread Traumatic Calvarial Defects: Case Report. J. Cranio Maxillo Fac. Surg. Off. Publ. Eur. Assoc. Cranio Maxillo Fac. Surg. 2004, 32, 370-373. [CrossRef] [PubMed]

8. Thesleff, T.; Lehtimäki, K.; Niskakangas, T.; Huovinen, S.; Mannerström, B.; Miettinen, S.; Seppänen-Kaijansinkko, R.; Öhman, J. Cranioplasty with Adipose-Derived Stem Cells, Beta-Tricalcium Phosphate Granules and Supporting Mesh: Six-Year Clinical Follow-Up Results. Stem Cells Transl. Med. 2017, 6, 1576-1582. [CrossRef]

9. Horch, R.E.; Beier, J.P.; Kneser, U.; Arkudas, A. Successful Human Long-Term Application of in Situ Bone Tissue Engineering. J. Cell. Mol. Med. 2014, 18, 1478-1485. [CrossRef]

10. Khojasteh, A.; Hosseinpour, S.; Rad, M.R.; Alikhasi, M. Buccal Fat Pad-Derived Stem Cells in Three-Dimensional Rehabilitation of Large Alveolar Defects: A Report of Two Cases. J. Oral Implantol. 2019, 45, 45-54. [CrossRef] [PubMed]

11. Storti, G.; Scioli, M.G.; Kim, B.-S.; Orlandi, A.; Cervelli, V. Adipose-Derived Stem Cells in Bone Tissue Engineering: Useful Tools with New Applications. Stem Cells Int. 2019, 2019, 3673857. [CrossRef] [PubMed]

12. Ntege, E.H.; Sunami, H.; Shimizu, Y. Advances in Regenerative Therapy: A Review of the Literature and Future Directions. Regen. Ther. 2020, 14, 136-153. [CrossRef] [PubMed]

13. Asatrian, G.; Pham, D.; Hardy, W.R.; James, A.W.; Peault, B. Stem Cell Technology for Bone Regeneration: Current Status and Potential Applications. Stem Cells Cloning Adv. Appl. 2015, 8, 39-48. [CrossRef]

14. Kern, S.; Eichler, H.; Stoeve, J.; Klüter, H.; Bieback, K. Comparative Analysis of Mesenchymal Stem Cells from Bone Marrow, Umbilical Cord Blood, or Adipose Tissue. Stem Cells Dayt. Ohio 2006, 24, 1294-1301. [CrossRef] [PubMed]

15. Burrow, K.L.; Hoyland, J.A.; Richardson, S.M. Human Adipose-Derived Stem Cells Exhibit Enhanced Proliferative Capacity and Retain Multipotency Longer than Donor-Matched Bone Marrow Mesenchymal Stem Cells during Expansion In Vitro. Stem Cells Int. 2017, 2017, 2541275. [CrossRef]

16. Le Blanc, K.; Frassoni, F.; Ball, L.; Locatelli, F.; Roelofs, H.; Lewis, I.; Lanino, E.; Sundberg, B.; Bernardo, M.E.; Remberger, M.; et al. Mesenchymal Stem Cells for Treatment of Steroid-Resistant, Severe, Acute Graft-versus-Host Disease: A Phase II Study. Lancet 2008, 371, 1579-1586. [CrossRef]

17. Tripathy, N.; Perumal, E.; Ahmad, R.; Song, J.E.; Khang, G. Chapter 40 - Hybrid composite biomaterials. In Principles of Regenerative Medicine, 3rd ed.; Atala, A., Lanza, R., Mikos, A.G., Nerem, R., Eds.; Academic Press: Boston, MA, USA, 2019; pp. 695-714. ISBN 978-0-12-809880-6.

18. Su, P.; Tian, Y.; Yang, C.; Ma, X.; Wang, X.; Pei, J.; Qian, A. Mesenchymal Stem Cell Migration during Bone Formation and Bone Diseases Therapy. Int. J. Mol. Sci. 2018, 19, 2343. [CrossRef]

19. Ghiasi, M.S.; Chen, J.; Vaziri, A.; Rodriguez, E.K.; Nazarian, A. Bone Fracture Healing in Mechanobiological Modeling: A Review of Principles and Methods. Bone Rep. 2017, 6, 87-100. [CrossRef] [PubMed]

20. Codrea, C.I.; Croitoru, A.-M.; Baciu, C.C.; Melinescu, A.; Ficai, D.; Fruth, V.; Ficai, A. Advances in Osteoporotic Bone Tissue Engineering. J. Clin. Med. 2021, 10, 253. [CrossRef] [PubMed]

21. Pereira, H.F.; Cengiz, I.F.; Silva, F.S.; Reis, R.L.; Oliveira, J.M. Scaffolds and Coatings for Bone Regeneration. J. Mater. Sci. Mater. Med. 2020, 31, 27. [CrossRef]

22. Vi, L.; Baht, G.S.; Whetstone, H.; Ng, A.; Wei, Q.; Poon, R.; Mylvaganam, S.; Grynpas, M.; Alman, B.A. Macrophages Promote Osteoblastic Differentiation In Vivo: Implications in Fracture Repair and Bone Homeostasis. J. Bone Miner. Res. 2015, 30, 1090-1102. [CrossRef]

23. Chang, M.K.; Raggatt, L.-J.; Alexander, K.A.; Kuliwaba, J.S.; Fazzalari, N.L.; Schroder, K.; Maylin, E.R.; Ripoll, V.M.; Hume, D.A.; Pettit, A.R. Osteal Tissue Macrophages Are Intercalated throughout Human and Mouse Bone Lining Tissues and Regulate Osteoblast Function In Vitro and In Vivo. J. Immunol. 2008, 181, 1232-1244. [CrossRef] [PubMed]

24. Murray, P.J. Macrophage Polarization. Annu. Rev. Physiol. 2017, 79, 541-566. [CrossRef]

25. Kang, M.; Huang, C.-C.; Lu, Y.; Shirazi, S.; Gajendrareddy, P.; Ravindran, S.; Cooper, L.F. Bone Regeneration Is Mediated by Macrophage Extracellular Vesicles. Bone 2020, 141, 115627. [CrossRef] [PubMed] 
26. Foulke, B.A.; Kendal, A.R.; Murray, D.W.; Pandit, H. Fracture Healing in the Elderly: A Review. Maturitas 2016, 92, 49-55. [CrossRef] [PubMed]

27. Infante, A.; Rodríguez, C.I. Osteogenesis and Aging: Lessons from Mesenchymal Stem Cells. Stem Cell Res. Ther. 2018, 9, 244. [CrossRef] [PubMed]

28. Nishikawa, K.; Nakashima, T.; Takeda, S.; Isogai, M.; Hamada, M.; Kimura, A.; Kodama, T.; Yamaguchi, A.; Owen, M.J.; Takahashi, S.; et al. Maf Promotes Osteoblast Differentiation in Mice by Mediating the Age-Related Switch in Mesenchymal Cell Differentiation. J. Clin. Invest. 2010, 120, 3455-3465. [CrossRef] [PubMed]

29. Li, H.; Liu, P.; Xu, S.; Li, Y.; Dekker, J.D.; Li, B.; Fan, Y.; Zhang, Z.; Hong, Y.; Yang, G.; et al. FOXP1 Controls Mesenchymal Stem Cell Commitment and Senescence during Skeletal Aging. J. Clin. Invest. 2017, 127, 1241-1253. [CrossRef]

30. Wu, M.; Wang, Y.; Shao, J.-Z.; Wang, J.; Chen, W.; Li, Y.-P. Cbf $\beta$ Governs Osteoblast-Adipocyte Lineage Commitment through Enhancing $\beta$-Catenin Signaling and Suppressing Adipogenesis Gene Expression. Proc. Natl. Acad. Sci. USA 2017, 114, 1011910124. [CrossRef]

31. Clark, D.; Nakamura, M.; Miclau, T.; Marcucio, R. Effects of Aging on Fracture Healing. Curr. Osteoporos. Rep. 2017, 15, 601-608. [CrossRef]

32. Pisani, P.; Renna, M.D.; Conversano, F.; Casciaro, E.; Di Paola, M.; Quarta, E.; Muratore, M.; Casciaro, S. Major Osteoporotic Fragility Fractures: Risk Factor Updates and Societal Impact. World J. Orthop. 2016, 7, 171-181. [CrossRef]

33. Tatehara, S.; Miyamoto, Y.; Takechi, M.; Momota, Y.; Yuasa, T. Osteoporosis Influences the Early Period of the Healing after Distraction Osteogenesis in a Rat Osteoporotic Model. J. Cranio Maxillo Fac. Surg. Off. Publ. Eur. Assoc. Cranio Maxillo Fac. Surg. 2011, 39, 2-9. [CrossRef]

34. Giannoudis, P.; Tzioupis, C.; Almalki, T.; Buckley, R. Fracture Healing in Osteoporotic Fractures: Is It Really Different? A Basic Science Perspective. Injury 2007, 38 (Suppl. 1), S90-S99. [CrossRef] [PubMed]

35. Zieba, J.; Munivez, E.; Castellon, A.; Jiang, M.-M.; Dawson, B.; Ambrose, C.G.; Lee, B. Fracture Healing in Collagen-Related Preclinical Models of Osteogenesis Imperfecta. J. Bone Miner. Res. Off. J. Am. Soc. Bone Miner. Res. 2020, 35, 1132-1148. [CrossRef] [PubMed]

36. Munns, C.F.; Rauch, F.; Zeitlin, L.; Fassier, F.; Glorieux, F.H. Delayed Osteotomy but Not Fracture Healing in Pediatric Osteogenesis Imperfecta Patients Receiving Pamidronate. J. Bone Miner. Res. Off. J. Am. Soc. Bone Miner. Res. 2004, 19, 1779-1786. [CrossRef] [PubMed]

37. Retzepi, M.; Donos, N. The Effect of Diabetes Mellitus on Osseous Healing. Clin. Oral Implants Res. 2010, 21, 673-681. [CrossRef]

38. Wallner, C.; Jaurich, H.; Wagner, J.M.; Becerikli, M.; Harati, K.; Dadras, M.; Lehnhardt, M.; Behr, B. Inhibition of GDF8 (Myostatin) Accelerates Bone Regeneration in Diabetes Mellitus Type 2. Sci. Rep. 2017, 7, 9878. [CrossRef]

39. Catalfamo, D.L.; Britten, T.M.; Storch, D.L.; Calderon, N.L.; Sorenson, H.L.; Wallet, S.M. Hyperglycemia Induced and Intrinsic Alterations in Type 2 Diabetes-Derived Osteoclast Function. Oral Dis. 2013, 19, 303-312. [CrossRef]

40. Sanguineti, R.; Storace, D.; Monacelli, F.; Federici, A.; Odetti, P. Pentosidine Effects on Human Osteoblasts in Vitro. Ann. N. Y. Acad. Sci. 2008, 1126, 166-172. [CrossRef]

41. Marrelli, M.; Tatullo, M.; Dipalma, G.; Inchingolo, F. Oral Infection by Staphylococcus Aureus in Patients Affected by White Sponge Nevus: A Description of Two Cases Occurred in the Same Family. Int. J. Med. Sci. 2012, 9, 47-50. [CrossRef]

42. Inchingolo, F.; Tatullo, M.; Abenavoli, F.M.; Marrelli, M.; Inchingolo, A.D.; Palladino, A.; Inchingolo, A.M.; Dipalma, G. Oral Piercing and Oral Diseases: A Short Time Retrospective Study. Int. J. Med. Sci. 2011, 8, 649-652. [CrossRef]

43. Depypere, M.; Morgenstern, M.; Kuehl, R.; Senneville, E.; Moriarty, T.F.; Obremskey, W.T.; Zimmerli, W.; Trampuz, A.; Lagrou, K.; Metsemakers, W.-J. Pathogenesis and Management of Fracture-Related Infection. Clin. Microbiol. Infect. Off. Publ. Eur. Soc. Clin. Microbiol. Infect. Dis. 2020, 26, 572-578. [CrossRef] [PubMed]

44. Yeler, H.; Tahtabas, F.; Candan, F. Investigation of Oxidative Stress during Fracture Healing in the Rats. Cell Biochem. Funct. 2005, 23, 137-139. [CrossRef]

45. Kubo, Y.; Wruck, C.J.; Fragoulis, A.; Drescher, W.; Pape, H.C.; Lichte, P.; Fischer, H.; Tohidnezhad, M.; Hildebrand, F.; Pufe, T.; et al. Role of Nrf2 in Fracture Healing: Clinical Aspects of Oxidative Stress. Calcif. Tissue Int. 2019, 105, 341-352. [CrossRef] [PubMed]

46. Ilyas, A.; Odatsu, T.; Shah, A.; Monte, F.; Kim, H.K.W.; Kramer, P.; Aswath, P.B.; Varanasi, V.G. Amorphous Silica: A New Antioxidant Role for Rapid Critical-Sized Bone Defect Healing. Adv. Healthc. Mater. 2016, 5, 2199-2213. [CrossRef]

47. Kelpke, S.S.; Reiff, D.; Prince, C.W.; Thompson, J.A. Acidic Fibroblast Growth Factor Signaling Inhibits Peroxynitrite-Induced Death of Osteoblasts and Osteoblast Precursors. J. Bone Miner. Res. Off. J. Am. Soc. Bone Miner. Res. 2001, 16, 1917-1925. [CrossRef]

48. Mittal, M.; Siddiqui, M.R.; Tran, K.; Reddy, S.P.; Malik, A.B. Reactive Oxygen Species in Inflammation and Tissue Injury. Antioxid. Redox Signal. 2014, 20, 1126-1167. [CrossRef]

49. Vanella, L.; Sanford, C.; Kim, D.H.; Abraham, N.G.; Ebraheim, N. Oxidative Stress and Heme Oxygenase-1 Regulated Human Mesenchymal Stem Cells Differentiation. Int. J. Hypertens. 2012, 2012, 890671. [CrossRef]

50. Mody, N.; Parhami, F.; Sarafian, T.A.; Demer, L.L. Oxidative Stress Modulates Osteoblastic Differentiation of Vascular and Bone Cells. Free Radic. Biol. Med. 2001, 31, 509-519. [CrossRef]

51. Callaway, D.A.; Jiang, J.X. Reactive Oxygen Species and Oxidative Stress in Osteoclastogenesis, Skeletal Aging and Bone Diseases. J. Bone Miner. Metab. 2015, 33, 359-370. [CrossRef] [PubMed]

52. Wauquier, F.; Leotoing, L.; Coxam, V.; Guicheux, J.; Wittrant, Y. Oxidative Stress in Bone Remodelling and Disease. Trends Mol. Med. 2009, 15, 468-477. [CrossRef] [PubMed] 
53. Wruck, C.J.; Claussen, M.; Fuhrmann, G.; Römer, L.; Schulz, A.; Pufe, T.; Waetzig, V.; Peipp, M.; Herdegen, T.; Götz, M.E. Luteolin Protects Rat PC12 and C6 Cells against MPP+ Induced Toxicity via an ERK Dependent Keap1-Nrf2-ARE Pathway. J. Neural Transm. Suppl. 2007, 57-67. [CrossRef]

54. Zhang, D.D. Mechanistic Studies of the Nrf2-Keap1 Signaling Pathway. Drug Metab. Rev. 2006, 38, 769-789. [CrossRef]

55. Lippross, S.; Beckmann, R.; Streubesand, N.; Ayub, F.; Tohidnezhad, M.; Campbell, G.; Kan, Y.W.; Horst, F.; Sönmez, T.T.; Varoga, D.; et al. Nrf2 Deficiency Impairs Fracture Healing in Mice. Calcif. Tissue Int. 2014, 95, 349-361. [CrossRef]

56. Duryee, M.J.; Dusad, A.; Hunter, C.D.; Kharbanda, K.K.; Bruenjes, J.D.; Easterling, K.C.; Siebler, J.C.; Thiele, G.M.; Chakkalakal, D.A. N-Acetyl Cysteine Treatment Restores Early Phase Fracture Healing in Ethanol-Fed Rats. Alcohol. Clin. Exp. Res. 2018, 42, 1206-1216. [CrossRef]

57. Kweider, N.; Fragoulis, A.; Rosen, C.; Pecks, U.; Rath, W.; Pufe, T.; Wruck, C.J. Interplay between Vascular Endothelial Growth Factor (VEGF) and Nuclear Factor Erythroid 2-Related Factor-2 (Nrf2): Implications for Preeclampsia. J. Biol. Chem. 2011, 286, 42863-42872. [CrossRef]

58. Kanzaki, H.; Shinohara, F.; Kajiya, M.; Kodama, T. The Keap1/Nrf2 Protein Axis Plays a Role in Osteoclast Differentiation by Regulating Intracellular Reactive Oxygen Species Signaling. J. Biol. Chem. 2013, 288, 23009-23020. [CrossRef]

59. Calori, G.M.; Mazza, E.; Colombo, M.; Ripamonti, C. The Use of Bone-Graft Substitutes in Large Bone Defects: Any Specific Needs? Injury 2011, 42 (Suppl. 2), S56-S63. [CrossRef]

60. Campana, V.; Milano, G.; Pagano, E.; Barba, M.; Cicione, C.; Salonna, G.; Lattanzi, W.; Logroscino, G. Bone Substitutes in Orthopaedic Surgery: From Basic Science to Clinical Practice. J. Mater. Sci. Mater. Med. 2014, 25, 2445-2461. [CrossRef]

61. Yoon, S.-W.; Kim, D.-K.; Kim, K.P.; Park, K.-S. Rad51 Regulates Cell Cycle Progression by Preserving G2/M Transition in Mouse Embryonic Stem Cells. Stem Cells Dev. 2014, 23, 2700-2711. [CrossRef]

62. Karp, J.M.; Ferreira, L.S.; Khademhosseini, A.; Kwon, A.H.; Yeh, J.; Langer, R.S. Cultivation of Human Embryonic Stem Cells without the Embryoid Body Step Enhances Osteogenesis in Vitro. Stem Cells Dayt. Ohio 2006, 24, 835-843. [CrossRef]

63. Aldahmash, A.; Atteya, M.; Elsafadi, M.; Al-Nbaheen, M.; Al-Mubarak, H.A.; Vishnubalaji, R.; Al-Roalle, A.; Al-Harbi, S.; Manikandan, M.; Matthaei, K.I.; et al. Teratoma Formation in Immunocompetent Mice after Syngeneic and Allogeneic Implantation of Germline Capable Mouse Embryonic Stem Cells. Asian Pac. J. Cancer Prev. 2013, 14, 5705-5711. [CrossRef]

64. Takahashi, K.; Yamanaka, S. Induction of Pluripotent Stem Cells from Mouse Embryonic and Adult Fibroblast Cultures by Defined Factors. Cell 2006, 126, 663-676. [CrossRef]

65. Takahashi, K.; Tanabe, K.; Ohnuki, M.; Narita, M.; Ichisaka, T.; Tomoda, K.; Yamanaka, S. Induction of Pluripotent Stem Cells from Adult Human Fibroblasts by Defined Factors. Cell 2007, 131, 861-872. [CrossRef]

66. Kao, C.-L.; Tai, L.-K.; Chiou, S.-H.; Chen, Y.-J.; Lee, K.-H.; Chou, S.-J.; Chang, Y.-L.; Chang, C.-M.; Chen, S.-J.; Ku, H.-H.; et al. Resveratrol Promotes Osteogenic Differentiation and Protects against Dexamethasone Damage in Murine Induced Pluripotent Stem Cells. Stem Cells Dev. 2010, 19, 247-258. [CrossRef] [PubMed]

67. Levi, B.; Hyun, J.S.; Montoro, D.T.; Lo, D.D.; Chan, C.K.F.; Hu, S.; Sun, N.; Lee, M.; Grova, M.; Connolly, A.J.; et al. In Vivo Directed Differentiation of Pluripotent Stem Cells for Skeletal Regeneration. Proc. Natl. Acad. Sci. USA 2012, 109, 20379-20384. [CrossRef]

68. Uto, S.; Nishizawa, S.; Takasawa, Y.; Asawa, Y.; Fujihara, Y.; Takato, T.; Hoshi, K. Bone and Cartilage Repair by Transplantation of Induced Pluripotent Stem Cells in Murine Joint Defect Model. Biomed. Res. Tokyo Jpn. 2013, 34, 281-288. [CrossRef]

69. Yu, J.; Vodyanik, M.A.; Smuga-Otto, K.; Antosiewicz-Bourget, J.; Frane, J.L.; Tian, S.; Nie, J.; Jonsdottir, G.A.; Ruotti, V.; Stewart, R.; et al. Induced Pluripotent Stem Cell Lines Derived from Human Somatic Cells. Science 2007, 318, 1917-1920. [CrossRef] [PubMed]

70. Riggs, J.W.; Barrilleaux, B.L.; Varlakhanova, N.; Bush, K.M.; Chan, V.; Knoepfler, P.S. Induced Pluripotency and Oncogenic Transformation Are Related Processes. Stem Cells Dev. 2013, 22, 37-50. [CrossRef]

71. Peterson, S.E.; Garitaonandia, I.; Loring, J.F. The Tumorigenic Potential of Pluripotent Stem Cells: What Can We Do to Minimize It? BioEssays News Rev. Mol. Cell. Dev. Biol. 2016, 38 (Suppl. 1), S86-S95. [CrossRef]

72. Friedenstein, A.J.; Chailakhjan, R.K.; Lalykina, K.S. The Development of Fibroblast Colonies in Monolayer Cultures of Guinea-Pig Bone Marrow and Spleen Cells. Cell Prolif. 1970, 3, 393-403. [CrossRef]

73. Caplan, A.I. Mesenchymal Stem Cells: Time to Change the Name! Stem Cells Transl. Med. 2017, 6, 1445-1451. [CrossRef]

74. Sipp, D.; Robey, P.G.; Turner, L. Clear up This Stem Cell Mess. Nature 2018, 561, 455-457. [CrossRef]

75. Squillaro, T.; Peluso, G.; Galderisi, U. Clinical Trials with Mesenchymal Stem Cells: An Update. Cell Transplant. 2016, 25, 829-848. [CrossRef] [PubMed]

76. Dominici, M.; Le Blanc, K.; Mueller, I.; Slaper-Cortenbach, I.; Marini, F.; Krause, D.; Deans, R.; Keating, A.; Prockop, D.; Horwitz, E. Minimal Criteria for Defining Multipotent Mesenchymal Stromal Cells. The International Society for Cellular Therapy Position Statement. Cytotherapy 2006, 8, 315-317. [CrossRef] [PubMed]

77. Corselli, M.; Crisan, M.; Murray, I.R.; West, C.C.; Scholes, J.; Codrea, F.; Khan, N.; Péault, B. Identification of Perivascular Mesenchymal Stromal/Stem Cells by Flow Cytometry. Cytom. Part J. Int. Soc. Anal. Cytol. 2013, 83, 714-720. [CrossRef]

78. Hinken, A.C.; Billin, A.N. Isolation of skeletal muscle stem cells for phenotypic screens for modulators of proliferation. In Phenotypic Screening: Methods and Protocols; Wagner, B., Ed.; Methods in Molecular Biology; Springer: New York, NY, USA, 2018; pp. 77-86. ISBN 978-1-4939-7847-2. 
79. Heo, J.S.; Choi, Y.; Kim, H.-S.; Kim, H.O. Comparison of Molecular Profiles of Human Mesenchymal Stem Cells Derived from Bone Marrow, Umbilical Cord Blood, Placenta and Adipose Tissue. Int. J. Mol. Med. 2016, 37, 115-125. [CrossRef]

80. Ojeh, N.; Pastar, I.; Tomic-Canic, M.; Stojadinovic, O. Stem Cells in Skin Regeneration, Wound Healing, and Their Clinical Applications. Int. J. Mol. Sci. 2015, 16, 25476-25501. [CrossRef]

81. Stanko, P.; Altanerova, U.; Jakubechova, J.; Repiska, V.; Altaner, C. Dental Mesenchymal Stem/Stromal Cells and Their Exosomes. Stem Cells Int. 2018, 2018, 8973613. [CrossRef]

82. Wakitani, S.; Imoto, K.; Yamamoto, T.; Saito, M.; Murata, N.; Yoneda, M. Human Autologous Culture Expanded Bone Marrow Mesenchymal Cell Transplantation for Repair of Cartilage Defects in Osteoarthritic Knees. Osteoarthr. Cartil. 2002, 10, 199-206. [CrossRef] [PubMed]

83. Zuk, P.A.; Zhu, M.; Ashjian, P.; De Ugarte, D.A.; Huang, J.I.; Mizuno, H.; Alfonso, Z.C.; Fraser, J.K.; Benhaim, P.; Hedrick, M.H. Human Adipose Tissue Is a Source of Multipotent Stem Cells. Mol. Biol. Cell 2002, 13, 4279-4295. [CrossRef]

84. Dadras, M.; May, C.; Wagner, J.M.; Wallner, C.; Becerikli, M.; Dittfeld, S.; Serschnitzki, B.; Schilde, L.; Guntermann, A.; Sengstock, C.; et al. Comparative Proteomic Analysis of Osteogenic Differentiated Human Adipose Tissue and Bone Marrow-Derived Stromal Cells. J. Cell. Mol. Med. 2020, 24, 11814-11827. [CrossRef]

85. Friedenstein, A.J. Osteogenic stem cells in bone marrow. Heersche, J.N.M., Kanis, J.A., Eds.; In Bone and Mineral Research; Elsevier: Amsterdam, The Netherlands, 1990; pp. 243-272.

86. Bennett, J.H.; Joyner, C.J.; Triffitt, J.T.; Owen, M.E. Adipocytic Cells Cultured from Marrow Have Osteogenic Potential. J. Cell Sci. 1991, 99 Pt 1, 131-139.

87. Zhao, J.; Yang, C.; Su, C.; Yu, M.; Zhang, X.; Huang, S.; Li, G.; Yu, M.; Li, X. Reconstruction of Orbital Defects by Implantation of Antigen-Free Bovine Cancellous Bone Scaffold Combined with Bone Marrow Mesenchymal Stem Cells in Rats. Graefes Arch. Clin. Exp. Ophthalmol. Albrecht Von Graefes Arch. Klin. Exp. Ophthalmol. 2013, 251, 1325-1333. [CrossRef] [PubMed]

88. Yueyi, C.; Xiaoguang, H.; Jingying, W.; Quansheng, S.; Jie, T.; Xin, F.; Yingsheng, X.; Chunli, S. Calvarial Defect Healing by Recruitment of Autogenous Osteogenic Stem Cells Using Locally Applied Simvastatin. Biomaterials 2013, 34, 9373-9380. [CrossRef] [PubMed]

89. Izadpanah, R.; Trygg, C.; Patel, B.; Kriedt, C.; Dufour, J.; Gimble, J.M.; Bunnell, B.A. Biologic Properties of Mesenchymal Stem Cells Derived from Bone Marrow and Adipose Tissue. J. Cell. Biochem. 2006, 99, 1285-1297. [CrossRef]

90. Wagner, W.; Horn, P.; Castoldi, M.; Diehlmann, A.; Bork, S.; Saffrich, R.; Benes, V.; Blake, J.; Pfister, S.; Eckstein, V.; et al. Replicative Senescence of Mesenchymal Stem Cells: A Continuous and Organized Process. PLoS ONE 2008, 3, e2213. [CrossRef]

91. Izadpanah, R.; Kaushal, D.; Kriedt, C.; Tsien, F.; Patel, B.; Dufour, J.; Bunnell, B.A. Long-Term in Vitro Expansion Alters the Biology of Adult Mesenchymal Stem Cells. Cancer Res. 2008, 68, 4229-4238. [CrossRef]

92. Bourin, P.; Bunnell, B.A.; Casteilla, L.; Dominici, M.; Katz, A.J.; March, K.L.; Redl, H.; Rubin, J.P.; Yoshimura, K.; Gimble, J.M. Stromal Cells from the Adipose Tissue-Derived Stromal Vascular Fraction and Culture Expanded Adipose Tissue-Derived Stromal/Stem Cells: A Joint Statement of the International Federation for Adipose Therapeutics and Science (IFATS) and the International Society for Cellular Therapy (ISCT). Cytotherapy 2013, 15, 641-648. [CrossRef]

93. Xu, L.; Liu, Y.; Sun, Y.; Wang, B.; Xiong, Y.; Lin, W.; Wei, Q.; Wang, H.; He, W.; Wang, B.; et al. Tissue Source Determines the Differentiation Potentials of Mesenchymal Stem Cells: A Comparative Study of Human Mesenchymal Stem Cells from Bone Marrow and Adipose Tissue. Stem Cell Res. Ther. 2017, 8. [CrossRef]

94. Mohamed-Ahmed, S.; Yassin, M.A.; Rashad, A.; Espedal, H.; Idris, S.B.; Finne-Wistrand, A.; Mustafa, K.; Vindenes, H.; Fristad, I. Comparison of Bone Regenerative Capacity of Donor-Matched Human Adipose-Derived and Bone Marrow Mesenchymal Stem Cells. Cell Tissue Res. 2021, 383, 1061-1075. [CrossRef]

95. Kargozar, S.; Mozafari, M.; Hashemian, S.J.; Brouki Milan, P.; Hamzehlou, S.; Soleimani, M.; Joghataei, M.T.; Gholipourmalekabadi, M.; Korourian, A.; Mousavizadeh, K.; et al. Osteogenic Potential of Stem Cells-Seeded Bioactive Nanocomposite Scaffolds: A Comparative Study between Human Mesenchymal Stem Cells Derived from Bone, Umbilical Cord Wharton's Jelly, and Adipose Tissue. J. Biomed. Mater. Res. B Appl. Biomater. 2018, 106, 61-72. [CrossRef]

96. Im, G.-I.; Shin, Y.-W.; Lee, K.-B. Do Adipose Tissue-Derived Mesenchymal Stem Cells Have the Same Osteogenic and Chondrogenic Potential as Bone Marrow-Derived Cells? Osteoarthr. Cartil. 2005, 13, 845-853. [CrossRef] [PubMed]

97. Kang, B.-J.; Ryu, H.-H.; Park, S.S.; Koyama, Y.; Kikuchi, M.; Woo, H.-M.; Kim, W.H.; Kweon, O.-K. Comparing the Osteogenic Potential of Canine Mesenchymal Stem Cells Derived from Adipose Tissues, Bone Marrow, Umbilical Cord Blood, and Wharton's Jelly for Treating Bone Defects. J. Vet. Sci. 2012, 13, 299-310. [CrossRef]

98. Stockmann, P.; Park, J.; von Wilmowsky, C.; Nkenke, E.; Felszeghy, E.; Dehner, J.-F.; Schmitt, C.; Tudor, C.; Schlegel, K.A. Guided Bone Regeneration in Pig Calvarial Bone Defects Using Autologous Mesenchymal Stem/Progenitor Cells - a Comparison of Different Tissue Sources. J. Cranio Maxillo Fac. Surg. Off. Publ. Eur. Assoc. Cranio Maxillo Fac. Surg. 2012, 40, 310-320. [CrossRef]

99. Boquest, A.C.; Shahdadfar, A.; Brinchmann, J.E.; Collas, P. Isolation of Stromal Stem Cells from Human Adipose Tissue. Methods Mol. Biol. 2006, 325, 35-46. [CrossRef]

100. Aust, L.; Devlin, B.; Foster, S.J.; Halvorsen, Y.D.C.; Hicok, K.; du Laney, T.; Sen, A.; Willingmyre, G.D.; Gimble, J.M. Yield of Human Adipose-Derived Adult Stem Cells from Liposuction Aspirates. Cytotherapy 2004, 6, 7-14. [CrossRef]

101. Hong, P.; Yang, H.; Wu, Y.; Li, K.; Tang, Z. The Functions and Clinical Application Potential of Exosomes Derived from Adipose Mesenchymal Stem Cells: A Comprehensive Review. Stem Cell Res. Ther. 2019, 10, 242. [CrossRef] 
102. Niemeyer, P.; Kornacker, M.; Mehlhorn, A.; Seckinger, A.; Vohrer, J.; Schmal, H.; Kasten, P.; Eckstein, V.; Südkamp, N.P.; Krause, U. Comparison of Immunological Properties of Bone Marrow Stromal Cells and Adipose Tissue-Derived Stem Cells before and after Osteogenic Differentiation in Vitro. Tissue Eng. 2007, 13, 111-121. [CrossRef]

103. Zhang, J.; Huang, X.; Wang, H.; Liu, X.; Zhang, T.; Wang, Y.; Hu, D. The Challenges and Promises of Allogeneic Mesenchymal Stem Cells for Use as a Cell-Based Therapy. Stem Cell Res. Ther. 2015, 6, 234. [CrossRef] [PubMed]

104. Zimmerlin, L.; Donnenberg, V.S.; Pfeifer, M.E.; Meyer, E.M.; Péault, B.; Rubin, J.P.; Donnenberg, A.D. Stromal Vascular Progenitors in Adult Human Adipose Tissue. Cytom. Part J. Int. Soc. Anal. Cytol. 2010, 77, 22-30. [CrossRef]

105. Yoshimura, K.; Shigeura, T.; Matsumoto, D.; Sato, T.; Takaki, Y.; Aiba-Kojima, E.; Sato, K.; Inoue, K.; Nagase, T.; Koshima, I.; et al. Characterization of Freshly Isolated and Cultured Cells Derived from the Fatty and Fluid Portions of Liposuction Aspirates. J. Cell. Physiol. 2006, 208, 64-76. [CrossRef]

106. Oedayrajsingh-Varma, M.J.; van Ham, S.M.; Knippenberg, M.; Helder, M.N.; Klein-Nulend, J.; Schouten, T.E.; Ritt, M.J.P.F.; van Milligen, F.J. Adipose Tissue-Derived Mesenchymal Stem Cell Yield and Growth Characteristics Are Affected by the Tissue-Harvesting Procedure. Cytotherapy 2006, 8, 166-177. [CrossRef]

107. Van Harmelen, V.; Röhrig, K.; Hauner, H. Comparison of Proliferation and Differentiation Capacity of Human Adipocyte Precursor Cells from the Omental and Subcutaneous Adipose Tissue Depot of Obese Subjects. Metabolism 2004, 53, 632-637. [CrossRef]

108. Guilak, F.; Lott, K.E.; Awad, H.A.; Cao, Q.; Hicok, K.C.; Fermor, B.; Gimble, J.M. Clonal Analysis of the Differentiation Potential of Human Adipose-Derived Adult Stem Cells. J. Cell. Physiol. 2006, 206, 229-237. [CrossRef] [PubMed]

109. Romagnoli, C.; Brandi, M.L. Adipose Mesenchymal Stem Cells in the Field of Bone Tissue Engineering. World J. Stem Cells 2014, 6, 144-152. [CrossRef] [PubMed]

110. Weigand, A.; Beier, J.P.; Schmid, R.; Knorr, T.; Kilian, D.; Götzl, R.; Gerber, T.; Horch, R.E.; Boos, A.M. Bone Tissue Engineering Under Xenogeneic-Free Conditions in a Large Animal Model as a Basis for Early Clinical Applicability. Tissue Eng. Part A 2016, 23, 208-222. [CrossRef] [PubMed]

111. Markarian, C.F.; Frey, G.Z.; Silveira, M.D.; Chem, E.M.; Milani, A.R.; Ely, P.B.; Horn, A.P.; Nardi, N.B.; Camassola, M. Isolation of Adipose-Derived Stem Cells: A Comparison among Different Methods. Biotechnol. Lett. 2014, 36, 693-702. [CrossRef]

112. Shafaei, H.; Kalarestaghi, H. Adipose-Derived Stem Cells: An Appropriate Selection for Osteogenic Differentiation. J. Cell. Physiol. 2020, 235, 8371-8386. [CrossRef] [PubMed]

113. Komori, T. Regulation of Osteoblast Differentiation by Transcription Factors. J. Cell. Biochem. 2006, 99, 1233-1239. [CrossRef]

114. Nakashima, K.; Zhou, X.; Kunkel, G.; Zhang, Z.; Deng, J.M.; Behringer, R.R.; de Crombrugghe, B. The Novel Zinc FingerContaining Transcription Factor Osterix Is Required for Osteoblast Differentiation and Bone Formation. Cell 2002, 108, 17-29. [CrossRef]

115. Jimi, E.; Hirata, S.; Shin, M.; Yamazaki, M.; Fukushima, H. Molecular Mechanisms of BMP-Induced Bone Formation: Cross-Talk between BMP and NF-KB Signaling Pathways in Osteoblastogenesis. Jpn. Dent. Sci. Rev. 2010, 46, 33-42. [CrossRef]

116. Long, F. Building Strong Bones: Molecular Regulation of the Osteoblast Lineage. Nat. Rev. Mol. Cell Biol. 2012, 13, 27-38. [CrossRef]

117. Yang, J.; Andre, P.; Ye, L.; Yang, Y.-Z. The Hedgehog Signalling Pathway in Bone Formation. Int. J. Oral Sci. 2015, 7, 73-79. [CrossRef]

118. Senarath-Yapa, K.; McArdle, A.; Renda, A.; Longaker, M.T.; Quarto, N. Adipose-Derived Stem Cells: A Review of Signaling Networks Governing Cell Fate and Regenerative Potential in the Context of Craniofacial and Long Bone Skeletal Repair. Int. J. Mol. Sci. 2014, 15, 9314-9330. [CrossRef]

119. Hojo, H.; Ohba, S.; Chung, U. Signaling Pathways Regulating the Specification and Differentiation of the Osteoblast Lineage. Regen. Ther. 2015, 1, 57-62. [CrossRef]

120. Houschyar, K.S.; Tapking, C.; Borrelli, M.R.; Popp, D.; Duscher, D.; Maan, Z.N.; Chelliah, M.P.; Li, J.; Harati, K.; Wallner, C.; et al. Wnt Pathway in Bone Repair and Regeneration - What Do We Know So Far. Front. Cell Dev. Biol. 2019, 6. [CrossRef] [PubMed]

121. James, A.W. Review of Signaling Pathways Governing MSC Osteogenic and Adipogenic Differentiation. Scientifica 2013, 2013, 684736. [CrossRef]

122. McCullen, S.D.; Haslauer, C.M.; Loboa, E.G. Musculoskeletal Mechanobiology: Interpretation by External Force and Engineered Substratum. J. Biomech. 2010, 43, 119-127. [CrossRef]

123. Langenbach, F.; Handschel, J. Effects of Dexamethasone, Ascorbic Acid and $\beta$-Glycerophosphate on the Osteogenic Differentiation of Stem Cells in Vitro. Stem Cell Res. Ther. 2013, 4, 117. [CrossRef] [PubMed]

124. Kornicka, K.; Marycz, K.; Tomaszewski, K.A.; Marędziak, M.; Śmieszek, A. The Effect of Age on Osteogenic and Adipogenic Differentiation Potential of Human Adipose Derived Stromal Stem Cells (HASCs) and the Impact of Stress Factors in the Course of the Differentiation Process. Oxid. Med. Cell. Longev. 2015, 2015, 309169. [CrossRef]

125. Patrikoski, M.; Mannerström, B.; Miettinen, S. Perspectives for Clinical Translation of Adipose Stromal/Stem Cells. Stem Cells Int. 2019, 2019, 5858247. [CrossRef]

126. Lieberman, J.R.; Daluiski, A.; Einhorn, T.A. The Role of Growth Factors in the Repair of Bone. Biology and Clinical Applications. J. Bone Joint Surg. Am. 2002, 84, 1032-1044. [CrossRef]

127. Grottkau, B.E.; Lin, Y. Osteogenesis of Adipose-Derived Stem Cells. Bone Res. 2013, 1, 133-145. [CrossRef] 
128. Govender, S.; Csimma, C.; Genant, H.K.; Valentin-Opran, A.; Amit, Y.; Arbel, R.; Aro, H.; Atar, D.; Bishay, M.; Börner, M.G.; et al. Recombinant Human Bone Morphogenetic Protein-2 for Treatment of Open Tibial Fractures: A Prospective, Controlled, Randomized Study of Four Hundred and Fifty Patients. J. Bone Joint Surg. Am. 2002, 84, 2123-2134. [CrossRef]

129. Malladi, P.; Xu, Y.; Yang, G.P.; Longaker, M.T. Functions of Vitamin D, Retinoic Acid, and Dexamethasone in Mouse AdiposeDerived Mesenchymal Cells. Tissue Eng. 2006, 12, 2031-2040. [CrossRef] [PubMed]

130. Wang, C.-Z.; Chen, S.-M.; Chen, C.-H.; Wang, C.-K.; Wang, G.-J.; Chang, J.-K.; Ho, M.-L. The Effect of the Local Delivery of Alendronate on Human Adipose-Derived Stem Cell-Based Bone Regeneration. Biomaterials 2010, 31, 8674-8683. [CrossRef]

131. Zheng, C.; Wang, J.; Liu, Y.; Yu, Q.; Liu, Y.; Deng, N.; Liu, J. Functional Selenium Nanoparticles Enhanced Stem Cell Osteoblastic Differentiation through BMP Signaling Pathways. Adv. Funct. Mater. 2014, 24, 6872-6883. [CrossRef]

132. Scioli, M.G.; Bielli, A.; Gentile, P.; Cervelli, V.; Orlandi, A. Combined Treatment with Platelet-Rich Plasma and Insulin Favours Chondrogenic and Osteogenic Differentiation of Human Adipose-Derived Stem Cells in Three-Dimensional Collagen Scaffolds. J. Tissue Eng. Regen. Med. 2017, 11, 2398-2410. [CrossRef]

133. Chow, J.C.; Young, D.W.; Golenbock, D.T.; Christ, W.J.; Gusovsky, F. Toll-like Receptor-4 Mediates Lipopolysaccharide-Induced Signal Transduction. J. Biol. Chem. 1999, 274, 10689-10692. [CrossRef]

134. Herzmann, N.; Salamon, A.; Fiedler, T.; Peters, K. Lipopolysaccharide Induces Proliferation and Osteogenic Differentiation of Adipose-Derived Mesenchymal Stromal Cells in Vitro via TLR4 Activation. Exp. Cell Res. 2017, 350, 115-122. [CrossRef]

135. Hess, K.; Ushmorov, A.; Fiedler, J.; Brenner, R.E.; Wirth, T. TNFalpha Promotes Osteogenic Differentiation of Human Mesenchymal Stem Cells by Triggering the NF-KappaB Signaling Pathway. Bone 2009, 45, 367-376. [CrossRef] [PubMed]

136. Fiedler, T.; Salamon, A.; Adam, S.; Herzmann, N.; Taubenheim, J.; Peters, K. Impact of Bacteria and Bacterial Components on Osteogenic and Adipogenic Differentiation of Adipose-Derived Mesenchymal Stem Cells. Exp. Cell Res. 2013, 319, $2883-2892$. [CrossRef]

137. Ruhl, T.; Kim, B.-S.; Beier, J.P. Cannabidiol Restores Differentiation Capacity of LPS Exposed Adipose Tissue Mesenchymal Stromal Cells. Exp. Cell Res. 2018, 370, 653-662. [CrossRef]

138. Wang, L.-L.; Zhao, R.; Li, J.-Y.; Li, S.-S.; Liu, M.; Wang, M.; Zhang, M.-Z.; Dong, W.-W.; Jiang, S.-K.; Zhang, M.; et al. Pharmacological Activation of Cannabinoid 2 Receptor Attenuates Inflammation, Fibrogenesis, and Promotes Re-Epithelialization during Skin Wound Healing. Eur. J. Pharmacol. 2016, 786, 128-136. [CrossRef]

139. Raphael, B.; Gabet, Y. The Skeletal Endocannabinoid System: Clinical and Experimental Insights. J. Basic Clin. Physiol. Pharmacol. 2016, 27, 237-245. [CrossRef] [PubMed]

140. Schmuhl, E.; Ramer, R.; Salamon, A.; Peters, K.; Hinz, B. Increase of Mesenchymal Stem Cell Migration by Cannabidiol via Activation of P42/44 MAPK. Biochem. Pharmacol. 2014, 87, 489-501. [CrossRef]

141. Ruhl, T.; Schneider, P.-A.; Kim, B.-S.; Beier, J.P. Endocannabinoids Increase Human Adipose Stem Cell Differentiation and Growth Factor Secretion in Vitro. J. Tissue Eng. Regen. Med. 2021, 15, 88-98. [CrossRef]

142. Steward, A.J.; Kelly, D.J. Mechanical Regulation of Mesenchymal Stem Cell Differentiation. J. Anat. 2015, 227, 717-731. [CrossRef]

143. Virjula, S.; Zhao, F.; Leivo, J.; Vanhatupa, S.; Kreutzer, J.; Vaughan, T.J.; Honkala, A.-M.; Viehrig, M.; Mullen, C.A.; Kallio, P.; et al. The Effect of Equiaxial Stretching on the Osteogenic Differentiation and Mechanical Properties of Human Adipose Stem Cells. J. Mech. Behav. Biomed. Mater. 2017, 72, 38-48. [CrossRef]

144. Fang, B.; Liu, Y.; Zheng, D.; Shan, S.; Wang, C.; Gao, Y.; Wang, J.; Xie, Y.; Zhang, Y.; Li, Q. The Effects of Mechanical Stretch on the Biological Characteristics of Human Adipose-Derived Stem Cells. J. Cell. Mol. Med. 2019, 23, 4244-4255. [CrossRef]

145. Marrelli, M.; Codispoti, B.; Shelton, R.M.; Scheven, B.A.; Cooper, P.R.; Tatullo, M.; Paduano, F. Dental Pulp Stem Cell Mechanoresponsiveness: Effects of Mechanical Stimuli on Dental Pulp Stem Cell Behavior. Front. Physiol. 2018, 9, 1685. [CrossRef] [PubMed]

146. Lee, S.-K.; Min, K.-S.; Kim, Y.-; Jeong, G.-S.; Lee, S.-H.; Lee, H.-J.; Lee, S.-I.; Kim, Y.-S.; Lee, Y.-M.; Park, S.-J.; et al. Mechanical Stress Activates Proinflammatory Cytokines and Antioxidant Defense Enzymes in Human Dental Pulp Cells. J. Endod. 2008, 34, 1364-1369. [CrossRef]

147. Safavi, A.S.; Rouhi, G.; Haghighipour, N.; Bagheri, F.; Eslaminejad, M.B.; Sayahpour, F.A. Efficacy of Mechanical Vibration in Regulating Mesenchymal Stem Cells Gene Expression. In Vitro Cell. Dev. Biol. Anim. 2019, 55, 387-394. [CrossRef]

148. Prè, D.; Ceccarelli, G.; Gastaldi, G.; Asti, A.; Saino, E.; Visai, L.; Benazzo, F.; Cusella De Angelis, M.G.; Magenes, G. The Differentiation of Human Adipose-Derived Stem Cells (HASCs) into Osteoblasts Is Promoted by Low Amplitude, High Frequency Vibration Treatment. Bone 2011, 49, 295-303. [CrossRef]

149. Tjabringa, G.S.; Vezeridis, P.S.; Zandieh-Doulabi, B.; Helder, M.N.; Wuisman, P.I.J.M.; Klein-Nulend, J. Polyamines Modulate Nitric Oxide Production and Cox-2 Gene Expression in Response to Mechanical Loading in Human Adipose Tissue-Derived Mesenchymal Stem Cells. Stem Cells 2006, 24, 2262-2269. [CrossRef]

150. Salazar, G.T.; Ohneda, O. Review of Biophysical Factors Affecting Osteogenic Differentiation of Human Adult Adipose-Derived Stem Cells. Biophys. Rev. 2013, 5, 11-28. [CrossRef]

151. Fröhlich, M.; Grayson, W.L.; Marolt, D.; Gimble, J.M.; Kregar-Velikonja, N.; Vunjak-Novakovic, G. Bone Grafts Engineered from Human Adipose-Derived Stem Cells in Perfusion Bioreactor Culture. Tissue Eng. Part A 2010, 16, 179-189. [CrossRef]

152. Hammerick, K.E.; James, A.W.; Huang, Z.; Prinz, F.B.; Longaker, M.T. Pulsed Direct Current Electric Fields Enhance Osteogenesis in Adipose-Derived Stromal Cells. Tissue Eng. Part A 2010, 16, 917-931. [CrossRef] [PubMed] 
153. Wagner, J.M.; Reinkemeier, F.; Wallner, C.; Dadras, M.; Huber, J.; Schmidt, S.V.; Drysch, M.; Dittfeld, S.; Jaurich, H.; Becerikli, M.; et al. Adipose-Derived Stromal Cells Are Capable of Restoring Bone Regeneration After Post-Traumatic Osteomyelitis and Modulate B-Cell Response. Stem Cells Transl. Med. 2019, 8, 1084-1091. [CrossRef]

154. EL Andaloussi, S.; Mäger, I.; Breakefield, X.O.; Wood, M.J.A. Extracellular Vesicles: Biology and Emerging Therapeutic Opportunities. Nat. Rev. Drug Discov. 2013, 12,347-357. [CrossRef]

155. Van Niel, G.; D’Angelo, G.; Raposo, G. Shedding Light on the Cell Biology of Extracellular Vesicles. Nat. Rev. Mol. Cell Biol. 2018, 19, 213-228. [CrossRef]

156. Boudreau, L.H.; Duchez, A.-C.; Cloutier, N.; Soulet, D.; Martin, N.; Bollinger, J.; Paré, A.; Rousseau, M.; Naika, G.S.; Lévesque, T.; et al. Platelets Release Mitochondria Serving as Substrate for Bactericidal Group IIA-Secreted Phospholipase A2 to Promote Inflammation. Blood 2014, 124, 2173-2183. [CrossRef] [PubMed]

157. Tricarico, C.; Clancy, J.; D'Souza-Schorey, C. Biology and Biogenesis of Shed Microvesicles. Small GTPases 2017, 8, $220-232$. [CrossRef] [PubMed]

158. Marolt Presen, D.; Traweger, A.; Gimona, M.; Redl, H. Mesenchymal Stromal Cell-Based Bone Regeneration Therapies: From Cell Transplantation and Tissue Engineering to Therapeutic Secretomes and Extracellular Vesicles. Front. Bioeng. Biotechnol. 2019, 7, 352. [CrossRef]

159. Simpson, R.J.; Lim, J.W.; Moritz, R.L.; Mathivanan, S. Exosomes: Proteomic Insights and Diagnostic Potential. Expert Rev. Proteomics 2009, 6, 267-283. [CrossRef]

160. Jeppesen, D.K.; Fenix, A.M.; Franklin, J.L.; Higginbotham, J.N.; Zhang, Q.; Zimmerman, L.J.; Liebler, D.C.; Ping, J.; Liu, Q.; Evans, R.; et al. Reassessment of Exosome Composition. Cell 2019, 177, 428-445.e18. [CrossRef] [PubMed]

161. Mathivanan, S.; Ji, H.; Simpson, R.J. Exosomes: Extracellular Organelles Important in Intercellular Communication. J. Proteomics 2010, 73, 1907-1920. [CrossRef]

162. Lösche, W.; Scholz, T.; Temmler, U.; Oberle, V.; Claus, R.A. Platelet-Derived Microvesicles Transfer Tissue Factor to Monocytes but Not to Neutrophils. Platelets 2004, 15, 109-115. [CrossRef] [PubMed]

163. Li, W.; Liu, Y.; Zhang, P.; Tang, Y.; Zhou, M.; Jiang, W.; Zhang, X.; Wu, G.; Zhou, Y. Tissue-Engineered Bone Immobilized with Human Adipose Stem Cells-Derived Exosomes Promotes Bone Regeneration. ACS Appl. Mater. Interfaces 2018, 10, 5240-5254. [CrossRef]

164. Zhang, J.; Liu, X.; Li, H.; Chen, C.; Hu, B.; Niu, X.; Li, Q.; Zhao, B.; Xie, Z.; Wang, Y. Exosomes/Tricalcium Phosphate Combination Scaffolds Can Enhance Bone Regeneration by Activating the PI3K/Akt Signaling Pathway. Stem Cell Res. Ther. 2016, 7, 136. [CrossRef] [PubMed]

165. Qin, Y.; Wang, L.; Gao, Z.; Chen, G.; Zhang, C. Bone Marrow Stromal/Stem Cell-Derived Extracellular Vesicles Regulate Osteoblast Activity and Differentiation in Vitro and Promote Bone Regeneration in Vivo. Sci. Rep. 2016, 6, 21961. [CrossRef] [PubMed]

166. Osugi, M.; Katagiri, W.; Yoshimi, R.; Inukai, T.; Hibi, H.; Ueda, M. Conditioned Media from Mesenchymal Stem Cells Enhanced Bone Regeneration in Rat Calvarial Bone Defects. Tissue Eng. Part A 2012, 18, 1479-1489. [CrossRef]

167. Furuta, T.; Miyaki, S.; Ishitobi, H.; Ogura, T.; Kato, Y.; Kamei, N.; Miyado, K.; Higashi, Y.; Ochi, M. Mesenchymal Stem Cell-Derived Exosomes Promote Fracture Healing in a Mouse Model. Stem Cells Transl. Med. 2016, 5, 1620-1630. [CrossRef]

168. Qi, X.; Zhang, J.; Yuan, H.; Xu, Z.; Li, Q.; Niu, X.; Hu, B.; Wang, Y.; Li, X. Exosomes Secreted by Human-Induced Pluripotent Stem Cell-Derived Mesenchymal Stem Cells Repair Critical-Sized Bone Defects through Enhanced Angiogenesis and Osteogenesis in Osteoporotic Rats. Int. J. Biol. Sci. 2016, 12, 836-849. [CrossRef]

169. Zhang, B.; Yin, Y.; Lai, R.C.; Tan, S.S.; Choo, A.B.H.; Lim, S.K. Mesenchymal Stem Cells Secrete Immunologically Active Exosomes. Stem Cells Dev. 2014, 23, 1233-1244. [CrossRef]

170. Harrell, C.R.; Fellabaum, C.; Jovicic, N.; Djonov, V.; Arsenijevic, N.; Volarevic, V. Molecular Mechanisms Responsible for Therapeutic Potential of Mesenchymal Stem Cell-Derived Secretome. Cells 2019, 8, 467. [CrossRef]

171. Zhu, Y.; Jia, Y.; Wang, Y.; Xu, J.; Chai, Y. Impaired Bone Regenerative Effect of Exosomes Derived from Bone Marrow Mesenchymal Stem Cells in Type 1 Diabetes. Stem Cells Transl. Med. 2019, 8, 593-605. [CrossRef]

172. Bianco, P.; Cao, X.; Frenette, P.S.; Mao, J.J.; Robey, P.G.; Simmons, P.J.; Wang, C.-Y. The Meaning, the Sense and the Significance: Translating the Science of Mesenchymal Stem Cells into Medicine. Nat. Med. 2013, 19, 35-42. [CrossRef]

173. Winkler, S.; Mutschall, H.; Biggemann, J.; Fey, T.; Greil, P.; Körner, C.; Weisbach, V.; Meyer-Lindenberg, A.; Arkudas, A.; Horch, R.E.; et al. Human Umbilical Vein Endothelial Cell Support Bone Formation of Adipose-Derived Stem Cell-Loaded and 3D-Printed Osteogenic Matrices in the Arteriovenous Loop Model. Tissue Eng. Part A 2020. [CrossRef]

174. Boos, A.M.; Loew, J.S.; Weigand, A.; Deschler, G.; Klumpp, D.; Arkudas, A.; Bleiziffer, O.; Gulle, H.; Kneser, U.; Horch, R.E.; et al. Engineering Axially Vascularized Bone in the Sheep Arteriovenous-Loop Model. J. Tissue Eng. Regen. Med. 2013, 7, 654-664. [CrossRef] [PubMed]

175. Weigand, A.; Beier, J.P.; Hess, A.; Gerber, T.; Arkudas, A.; Horch, R.E.; Boos, A.M. Acceleration of Vascularized Bone TissueEngineered Constructs in a Large Animal Model Combining Intrinsic and Extrinsic Vascularization. Tissue Eng. Part A 2015, 21, 1680-1694. [CrossRef] [PubMed]

176. Boos, A.M.; Weigand, A.; Deschler, G.; Gerber, T.; Arkudas, A.; Kneser, U.; Horch, R.E.; Beier, J.P. Autologous Serum Improves Bone Formation in a Primary Stable Silica-Embedded Nanohydroxyapatite Bone Substitute in Combination with Mesenchymal Stem Cells and RhBMP-2 in the Sheep Model. Int. J. Nanomedicine 2014, 9, 5317-5339. [CrossRef] [PubMed] 
177. Deng, Y.; Zhou, H.; Zou, D.; Xie, Q.; Bi, X.; Gu, P.; Fan, X. The Role of MiR-31-Modified Adipose Tissue-Derived Stem Cells in Repairing Rat Critical-Sized Calvarial Defects. Biomaterials 2013, 34, 6717-6728. [CrossRef]

178. Haimi, S.; Gorianc, G.; Moimas, L.; Lindroos, B.; Huhtala, H.; Räty, S.; Kuokkanen, H.; Sándor, G.K.; Schmid, C.; Miettinen, S.; et al. Characterization of Zinc-Releasing Three-Dimensional Bioactive Glass Scaffolds and Their Effect on Human Adipose Stem Cell Proliferation and Osteogenic Differentiation. Acta Biomater. 2009, 5, 3122-3131. [CrossRef] [PubMed]

179. Mehrabani, D.; Khodakaram-Tafti, A.; Shaterzadeh-Yazdi, H.; Zamiri, B.; Omidi, M. Comparison of the Regenerative Effect of Adipose-Derived Stem Cells, Fibrin Glue Scaffold, and Autologous Bone Graft in Experimental Mandibular Defect in Rabbit. Dent. Traumatol. Off. Publ. Int. Assoc. Dent. Traumatol. 2018, 34, 413-420. [CrossRef]

180. Di Bella, C.; Farlie, P.; Penington, A.J. Bone Regeneration in a Rabbit Critical-Sized Skull Defect Using Autologous AdiposeDerived Cells. Tissue Eng. Part A 2008, 14, 483-490. [CrossRef]

181. Ko, E.; Yang, K.; Shin, J.; Cho, S.-W. Polydopamine-Assisted Osteoinductive Peptide Immobilization of Polymer Scaffolds for Enhanced Bone Regeneration by Human Adipose-Derived Stem Cells. Biomacromolecules 2013, 14, 3202-3213. [CrossRef]

182. Thibault, R.A.; Mikos, A.G.; Kasper, F.K. Scaffold/Extracellular Matrix Hybrid Constructs for Bone-Tissue Engineering. Adv. Healthc. Mater. 2013, 2, 13-24. [CrossRef]

183. Levi, B.; James, A.W.; Nelson, E.R.; Vistnes, D.; Wu, B.; Lee, M.; Gupta, A.; Longaker, M.T. Human Adipose Derived Stromal Cells Heal Critical Size Mouse Calvarial Defects. PLoS ONE 2010, 5, e11177. [CrossRef]

184. Tatullo, M.; Spagnuolo, G.; Codispoti, B.; Zamparini, F.; Zhang, A.; Esposti, M.D.; Aparicio, C.; Rengo, C.; Nuzzolese, M.; Manzoli, L.; et al. PLA-Based Mineral-Doped Scaffolds Seeded with Human Periapical Cyst-Derived MSCs: A Promising Tool for Regenerative Healing in Dentistry. Materials 2019, 12, 597. [CrossRef]

185. Ho-Shui-Ling, A.; Bolander, J.; Rustom, L.E.; Johnson, A.W.; Luyten, F.P.; Picart, C. Bone Regeneration Strategies: Engineered Scaffolds, Bioactive Molecules and Stem Cells Current Stage and Future Perspectives. Biomaterials 2018, 180, 143-162. [CrossRef]

186. DiGiovanni, C.W.; Lin, S.S.; Baumhauer, J.F.; Daniels, T.; Younger, A.; Glazebrook, M.; Anderson, J.; Anderson, R.; Evangelista, P.; Lynch, S.E.; et al. Recombinant Human Platelet-Derived Growth Factor-BB and Beta-Tricalcium Phosphate (RhPDGF-BB/ $\beta$-TCP): An Alternative to Autogenous Bone Graft. J. Bone Joint Surg. Am. 2013, 95, 1184-1192. [CrossRef] [PubMed]

187. Zhang, H.; Kot, A.; Lay, Y.-A.E.; Fierro, F.A.; Chen, H.; Lane, N.E.; Yao, W. Acceleration of Fracture Healing by Overexpression of Basic Fibroblast Growth Factor in the Mesenchymal Stromal Cells. Stem Cells Transl. Med. 2017, 6, 1880-1893. [CrossRef]

188. Liao, Y.-H.; Chang, Y.-H.; Sung, L.-Y.; Li, K.-C.; Yeh, C.-L.; Yen, T.-C.; Hwang, S.-M.; Lin, K.-J.; Hu, Y.-C. Osteogenic Differentiation of Adipose-Derived Stem Cells and Calvarial Defect Repair Using Baculovirus-Mediated Co-Expression of BMP-2 and MiR-148b. Biomaterials 2014, 35, 4901-4910. [CrossRef] [PubMed]

189. Wang, Y.-H.; Wu, J.-Y.; Kong, S.C.; Chiang, M.-H.; Ho, M.-L.; Yeh, M.-L.; Chen, C.-H. Low Power Laser Irradiation and Human Adipose-Derived Stem Cell Treatments Promote Bone Regeneration in Critical-Sized Calvarial Defects in Rats. PLoS ONE 2018, 13, e0195337. [CrossRef] [PubMed]

190. Chen, Q.; Yang, Z.; Sun, S.; Huang, H.; Sun, X.; Wang, Z.; Zhang, Y.; Zhang, B. Adipose-Derived Stem Cells Modified Genetically in Vivo Promote Reconstruction of Bone Defects. Cytotherapy 2010, 12, 831-840. [CrossRef] [PubMed]

191. Sheyn, D.; Kallai, I.; Tawackoli, W.; Cohn Yakubovich, D.; Oh, A.; Su, S.; Da, X.; Lavi, A.; Kimelman-Bleich, N.; Zilberman, Y.; et al. Gene-Modified Adult Stem Cells Regenerate Vertebral Bone Defect in a Rat Model. Mol. Pharm. 2011, 8, 1592-1601. [CrossRef]

192. Qing, W.; Guang-Xing, C.; Lin, G.; Liu, Y. The Osteogenic Study of Tissue Engineering Bone with BMP2 and BMP7 Gene-Modified Rat Adipose-Derived Stem Cell. J. Biomed. Biotechnol. 2012, 2012, 410879. [CrossRef]

193. Vériter, S.; André, W.; Aouassar, N.; Poirel, H.A.; Lafosse, A.; Docquier, P.-L.; Dufrane, D. Human Adipose-Derived Mesenchymal Stem Cells in Cell Therapy: Safety and Feasibility in Different "Hospital Exemption" Clinical Applications. PLoS ONE 2015, 10, e0139566. [CrossRef] 